\title{
La Scala in the Aftermath of the Liberation, 25 April 1945 to 22 June 1946
}

Paola Merli

This is a pre-copyedited, author-produced version of an article accepted for publication in The Musical Quarterly following peer review. The version of record, Paola Merli, "La Scala in the Aftermath of the Liberation, 25 April 1945 to 22 June 1946," The Musical Quarterly 100, n. 2 (Summer 2017), 155-198, is available online at: https://doi.org/10.1093/musqt1/gdy002; DOI: 10.1093/musqt1/gdy002.

More than seventy years after the end of the Fascist regime in Italy, our knowledge of how music institutions dealt with their Fascist past is still limited. Despite some early attempts to publish accounts of the transformations generated by Mussolini's regime in musical production and life, ${ }^{1}$ from 1946 on this uncomfortable topic was set aside. In the mid-1960s, Marxist critics began to publish on music and Fascism, but in the polarized political context of the Cold War era, such work remained rare. ${ }^{2}$ Most writings on composers, performers, and institutions focused on their artistic production, disregarding or implicitly denying the Fascist context in which they had operated.

The impasse was eventually broken at the beginning of the 1980s, when Piero Santi, a former music critic of the Socialist organ Avanti!, launched a critique of the selective denial of the relationship between Fascism and music, and showed that the role of Fascism could only be understood by moving from an approach focused on artistic works to one that considered the role of the state apparatus and the bureaucracy. ${ }^{3}$ Expanding on Santi's claim, Luigi Pestalozza, then head of the music section of the Direzione (leadership body) of the Italian Communist Party, ${ }^{4}$ stated that it was necessary to put an end to the "silences" and "common- 
places," and to acknowledge that Fascism had produced fundamental structural changes in musical production and life, and that such changes were still determining factors in the organization of music. ${ }^{5} \mathrm{He}$ argued that the Fascist regime had strengthened the centralized organizational models for music created by the Liberal state, and had, based on the notion of the state as patron and benefactor, offered musicians work security through the organization of their professional life within the corporative system of labor relations, in which the employers and the employed of the different industries and professions were represented under the coordinating power of the state. Subsidies to music institutions, he noted, were subject to full compliance with elaborate regulations and detailed, centralized directives that touched on every aspect of musical life. Pestalozza further observed that mediation of the cultural aspects of the class conflict were achieved by segregating musical production into different cultural tastes, modes of delivery, and venues based on class and geographical divisions, privileges, and hierarchies. In his view, Fascist arrangements originated in the transformation of music institutions from private to public organizations. La Scala, which had become a public institution in 1920-21, was the model later adopted by the Fascist state to restructure all other major music organizations in Italy according to a highly centralized template that, far from being an invention of Fascism, was firmly rooted in the development of the Liberal state. Most crucially and problematically, after the end of Mussolini's regime, music legislation, institutional ownership, and organizational patterns, as well as protagonists and events, continued much as during the Fascist era. ${ }^{6}$

Pestalozza's continuity argument was substantiated by empirical research. Fiamma Nicolodi's seminal study of the relationship between music and politics under the Fascist regime, published in 1984 and based on newly released documents from the papers of Mussolini's private secretariat (Segreteria Particolare del Duce) at the Central State Archive, revealed that 
virtually all of the prominent Italian composers were, to a significant degree, involved with Fascism, and some even personally with the dictator. ${ }^{7}$ In a later contribution, Nicolodi traced the incremental development of the complex mechanism of centralized control of musical production and life set up under Fascism. ${ }^{8}$ She also noted that rather than changing the Fascist regulations of 1936 that had reorganized the main music institutions so as to subject them to indirect funding and strict control by the state, a law introduced in 1946 by the Communist minister of finance, Mauro Scoccimarro, further increased and extended the indirect statefunding system — one that only the most prestigious of them had enjoyed under Fascism—to all music institutions. Other minor legislation passed in 1949, 1953, and 1956 modified the ratio of funding but did not change the law of 1936, which remained in force until 1967. Moreover, although Mussolini’s Ministry of Popular Culture (Ministero della Cultura Popolare) was shut down shortly after the liberation of Rome in 1944, when the General Directorate of the Performing Arts (Direzione Generale dello Spettacolo) was constituted under the prime minister's office in 1948, several former officials in the Ministry's Theater Inspectorate (Ispettorato del Teatro) were reinstated, with some remaining in their job until retirement in the 1960s. ${ }^{9}$ Summarizing the findings of his wide-ranging project on music in the 1950s, Guido Salvetti concluded that continuity with Fascist arrangements had involved most aspects of Italian musical production and life at least until $1955 .^{10}$

Similar conclusions were reached about La Scala, the prototypical music institution of Fascism in Pestalozza's argument. Harvey Sachs reconstructed Arturo Toscanini's struggle during the 1920 s to protect the autonomy of the institution from political maneuvers designed to bring it under Fascist control. But when the conductor departed in 1929, La Scala became the battlefield of a political feud among Milanese Fascists till Jenner Mataloni, a Fascist official and the house's general manager since 1932, was appointed sovrintendente in 1936, 
having secured backing by the local Fascists as well as Mussolini's support. According to Sachs, the method of gaining political control over music institutions through the replacement of music experts with political figures, one established during the Fascist period, continued after the war and well into the late 1980 s. ${ }^{11}$ Luisa Zanoncelli located continuity with Fascist patterns in the repertory of La Scala until $1957 .{ }^{12}$

The continuity argument was extremely important in challenging earlier, implicit denials of the influence of Fascism on musical production and life during and after Mussolini's regime, but it has failed to offer a complete picture. By concentrating on the state, conceptualized as a set of apparatuses for the reproduction of social structures, Pestalozza interpreted trends in the organization of music that carried over from Liberal Italy and continued in the Fascist period as proto-Fascist templates, and trends in post-Liberation Italy that persisted from the Fascist period as a continuity of Fascist arrangements. ${ }^{13}$ In fact, these interpretations are often unwarranted. They overlook what can be called the "systemic consequences," for musical production and life, of political-institutional change - especially the reintroduction of political and social pluralism and democracy, which the Fascist regime had suppressed ${ }^{14}$ —as well as purposeful action to produce change. In this article, I will look at these questions in order to provide information, missing from the discussion so far, that is inconsistent with the findings of the continuity argument. I will first look at some of the systemic consequences of politicalinstitutional change, which affected all music institutions in the country, and then consider purposeful change through a reconstruction of the post-Liberation transition at La Scala, a key institution in the continuity argument. ${ }^{15}$

The choice of La Scala as an example in this article does not imply any special assumptions about the degree to which it was "fascistized." Fascist arts policy, unlike its Nazi equivalent, 
was careful not to pursue an official art of the state or to ban modernism or any other aesthetic movements. ${ }^{16}$ La Scala, in particular, was one of two institutions - the other was the Rome Opera — chosen by the Ministry of Popular Culture to organize and host, in 1942, two "cicli di musica contemporanea" (short seasons of contemporary music), whose programs included some of the work that Italy's allies in Nazi Germany had banned as "degenerate."17 Yet, as Santi and Pestalozza noted, and as Mabel Berezin further articulated in her work on theater, Fascist cultural policy functioned according to a model of "state paternalism" in which cultural products had a "relative autonomy" but the state controlled "the organizations of cultural producers." ${ }^{18}$ La Scala, as the model for Fascist reforms that aimed at bringing organizations of music production under state control, reflected the Fascist template well, with the objectives achieved in a timely fashion. This circumstance, nevertheless, does not automatically mean that it was more deeply fascistized than other music institutions as a result.

At the same time, I also do not want to propose that in the post-Liberation transition La Scala was representative of music institutions all over the country. Indeed, because of its location in the former "capital" of the armed Resistance against Mussolini's Nazi-supported Republic of Salò and the German occupation in Northern Italy, ${ }^{19}$ La Scala's political context was particularly favorable to change. Still, local political contexts radicalized by a protracted Resistance were common in the North. They were less common in the South, which had been liberated by the Allies. Yet, given the geopolitical differences in the liberation of Italy, the role of the Allied Military Government (AMG) in the different regions, and the slow advance of the liberation process from the south to the north of the peninsula over one and a half years, it is unlikely that any single music institution in the country can offer a typical case. The 
example of La Scala nonetheless throws direct light on the intention and ability of the Resistance movement to deal with the Fascist past in musical production and life.

To address the range and complexity of the political pressures, constraints, and considerations affecting La Scala during the transition, I will concentrate here on the crucial fourteen months from the liberation of Milan on 25 April 1945 to the amnesty decreed on 22 June 1946, which largely ended the sanctions imposed on Fascist organizations and individuals. The events that occurred in that short time period cannot be considered representative of the entire transition to post-Fascism, as the new Constitution only came into force on 1 January 1948 and the first general elections took place in April. ${ }^{20}$ However, in terms of political-institutional change, the period selected covers the end of racial discrimination; the dismantlement of the political organizations of the regime; the enforcement of the purges against Fascist individuals in public administration, the professions, and the management of key industries; the national election of the Constituent Assembly through universal suffrage, which included women for the first time; and the birth of the Republic through popular referendum. In the north of the country, the period also covers the first local elections. It therefore includes the reintroduction of social and political pluralism and of democracy in both its indirect and direct forms. The choice of this particular time frame also helps avoid the conflation of the effects of actual continuities inherited from Fascism within state apparatuses and the administration with those of the series of amnesties that were decreed beginning 22 June 1946, as well as with the first effects of Cold War politics, which in Italy in May 1947 marked the end of the era of antiFascist coalition governments and the beginning of a series of centrist governments that were supported by all right-wing parties represented in the Constituent Assembly. ${ }^{21}$ 
By considering unpublished records from La Scala's archives, I examine the application of the sanctions law and the roles played by the AMG, local government, and anti-Fascist political figures, as well as initiatives by the leadership of the institution itself to recruit staff who had lost their jobs due to racial legislation and political bias, and to address programs inherited from the Fascist period. As I will demonstrate, La Scala benefited from the systemic consequences of political-institutional change but also undertook purposeful action to address its Fascist past.

\section{Historical Continuities and Political-Institutional Change}

If the systemic consequences of political-institutional change are taken into consideration, the transformation of La Scala into a public institution in 1920-21 can hardly be considered a proto-Fascist development inherited by the Fascist regime from the Liberal state, as suggested by the continuity argument. It was carried out by a Socialist-led city administration after two decades of public discussion of the future role of that institution in Milanese society. ${ }^{22}$ The transformation established the juridical status of La Scala as ente autonomo, ${ }^{23}$ that is, as a public institution with its own statutes and in full ownership of the theater building (through transfer of the property from box owners and the municipality), able to pursue its statutory objectives with full autonomy and in receipt of indirect funding from the state and direct funding from a democratically elected local government, and with half of its eight board members and its president designated through vote by a democratically elected city council, with the additional stipulation that after the initial nine-year experimental administration all the board members should be designated by the city council. ${ }^{24}$

Autonomy, then, must have constituted a problem for the Fascist regime, and it may explain why the regime made early efforts to bring La Scala under its control— not to adopt but rather 
to curb the ente autonomo model. By the time the regime reorganized the Rome Opera in 1929 on the model of La Scala, La Scala's autonomy had already been curtailed through the 1926 reform of the local administrations of larger cities, which eliminated elected councils and replaced each elected mayor with an all-powerful podestà appointed by the head of government. ${ }^{25}$ After that reform, it was the podestà that designated the municipality's representatives on the board of music institutions. And when the Fascist regime reorganized the opera house of Florence in 1932 and, in 1936, those of Turin, Venice, Trieste, Verona, Genoa, Bologna, Naples, and Palermo according to the model of La Scala, the Milanese institution was already operating under a new statute issued in 1931. This statute had transferred the property of the theater building from the ente autonomo to the municipality, and dictated that the president of the institution was to be appointed by the head of government (Mussolini at the time) amongst those designated by the municipality, six instead of four board members were to be appointed by the Fascist podestà, and of the other four, one had to be appointed by the Ministry of National Education (Ministero dell'Educazione Nazionale), one by the Ministry of Corporations (Ministero delle Corporazioni) to represent the National Fascist Union of Musicians (Sindacato Nazionale Fascista dei Musicisti), one by the provincial government, and one by the Provincial Council of Economy (later of Corporative Economy). ${ }^{26}$ The statute was further amended in 1934 to increase the role of the corporative system by reducing the number of board members to be appointed by the municipality to four, with the additional proviso that two of them should be chosen amongst the representatives of the Fascist Association of Industrialists in the Performing Arts (Associazione Fascista delle Industrie dello Spettacolo) and the Federation of the Fascist Unions of the Performing Arts (Federazione dei Sindacati Fascisti dello Spettacolo). 
It was in this final form that the statute of La Scala was adopted by the Ministry of Propaganda as the model for the law of 1936, which was adopted to reorganize all the main opera houses in Italy. The 1936 law, however, further established that the podestà would serve as the president of the city's music institution, and that the Ministry of Propaganda (in 1937 renamed Ministry of Popular Culture) would appoint the sovrintendente after consultation with the podestà. Programs needed to be approved in advance by the Ministry, and the Theater Inspectorate could change the program or dates as well as recommend young singers selected by the organizations of the corporative system of the performing arts. ${ }^{27}$ Fascism thus created its own model, by undermining rather than adopting the template of the ente autonomo of La Scala created in 1920-21.

Similarly, the fact that the performing arts law of 1936, which had been designed with the goal of subjecting music institutions to state control, remained in place after Liberation does not in itself constitute evidence of a continuity with Fascism. The Fascist character had arguably depended on the existence of a range of agencies of the Fascist political and corporative system, and when these were abolished after Liberation, the law lost its Fascist character. After Liberation, all podestà were replaced with mayors who initially were appointed by the Committee of National Liberation (Comitato di Liberazione Nationale, CLN $)^{28}$ and from 1946 were democratically elected, and these mayors became presidents of music institutions and were consulted in the appointment of the sovrintendente. At the same time, the Ministry of Popular Culture, which by virtue of the 1936 law controlled all music institutions, was shut down shortly after the liberation of Rome in 1944. Its counterpart in the Salò Republic was eliminated during the liberation of Northern Italy and its minister, Fernando Mezzasoma, was captured together with Mussolini and fifteen other Fascist leaders, and was executed with them by the partisans on 28 April $1945 .{ }^{29}$ The cultural ministry was 
not reinstituted, and music institutions were entrusted to special commissioners appointed by the CLN government. In 1948, ministerial functions with regard to the organization of music were taken over by the office of the democratically designated prime minister. ${ }^{30}$ And although the 1936 law required that municipalities appoint representatives to the boards of music institutions, ${ }^{31}$ when the boards were reconstituted in 1948, those representatives were chosen by democratically elected city councils.

Finally, the 1936 law stipulated, in corporative fashion, that representatives of the National Fascist Union of Musicians, the Fascist Association of Industrialists in the Performing Arts, and the Federation of the Fascist Unions in the Performing Arts had to be included on the board of all music institutions, as well as of the national commission advising the Ministry. Continuity in legislation for the performing arts after the Liberation meant, without doubt, that these elements of the corporative system were retained in labor relations. However, this did not necessarily mean continuity with Fascism. Corporatism had been common throughout Continental Europe in the 1920s and 1930s. In Italy, it was rooted in both Catholic and Socialist traditions of working class mobilization. Fascism adopted these traditions in order to pull the working classes into the orbit of the Fascist unions, ${ }^{32}$ and because such tactic failed, it suppressed workers' rights to free representation, negotiation, and collective action (the right to strike), and restricted the existence of trade unions to Fascist ones, which alone had the right to negotiate collective agreements with employers. ${ }^{33}$ Workers' representatives were in reality Fascist officials appointed from above, whose role was that of controlling and coercing labor. Shortly after Liberation, Fascist unions were abolished, free and democratic trade unions linked to the anti-Fascist workers' parties were re-created, and the rights of representation, negotiation, and collective action were restored. ${ }^{34}$ It was the representatives of these free and democratic trade unions who, in the postwar period, sat on the new boards of 
music institutions and on the national commission vis-à-vis the employers' associations, participating in the decision-making processes within music institutions and within the national commission for the performing arts. ${ }^{35}$ Therefore, the 1936 performing arts legislation retained, on the whole, a relatively centralizing and corporative character after Liberation, but not a Fascist one.

The National Fund for the Assistance of Workers in the Performing Arts (Cassa Nazionale di Assistenza dei Lavoratori dello Spettacolo), established in 1934 by the Fascist regime as part of the corporative system to provide health services, national insurance, and pensions for artists and other workers in the performing arts, was also retained after Liberation; it was reconstituted as the National Insurance and Assistance Agency for Workers in the Performing Arts (Ente Nazionale di Previdenza e di Assistenza per i Lavoratori dello Spettacolo) in 1947. ${ }^{36}$ Arguably, these were attempts to preserve something viewed as useful for workers in the performing arts, no matter that these services had been created as part of the regime's efforts to win over, or retain, the workers' consensus. In the second half of the twentieth century, the establishment of this type of agency was an objective of many performing arts trade unions, as well as of many European governments.

\section{Applying the Sanctions Law against Fascism}

Most historians view the postwar purge of Italian Fascists as perfunctory, or even a failure. ${ }^{37}$ As Charles Maier has shown, the sanctions law had fundamental limitations that were the consequences of the shift to democracy: conceived as a legal rather than a political instrument, the law was significantly constrained by three factors: (1) the problem of establishing guilt retroactively (for events that occurred before passage of the law), (2) that those who had infringed on human rights generally had acted not as individuals but in 
affiliation with organizations, and (3) the requirement to avoid any new infringements on human rights by the new democratic system. As a result, and as in much of liberated Europe, purges were largely symbolic. ${ }^{38}$ Even so, Hans Woller has found that Italian purges, though hastily terminated by amnesties, were extensive: most Fascists were put on trial, many went to prison, a very large number lost their jobs, and some continued to be socially marginalized and excluded throughout the 1950 s. ${ }^{39}$

Laws and guidelines for dealing with Fascist individuals, institutions, and legislation were promulgated by the AMG, the Italian government, and the CLN beginning in late 1943, with each new decree adding to or modifying earlier ones. ${ }^{40}$ Besides the dissolution of the Fascist Party and of all the institutions and political organs created by Fascism, the punishment of Fascist crimes, and the confiscation and liquidation of any profits, properties, and assets acquired by the Party and by individuals through participation in the activities of the regime, the legislation also stipulated the removal of compromised individuals from any public administration, as well as from professions, institutions, and any private companies considered of national interest or delivering public services. Criteria for removal included active participation in Fascist life; repeated apologies for Fascism; posts or career advancement earned through support of the Fascist Party or its hierarchies; profits or advantages gained through the abuse of power, corruption, or other forms of dishonesty; and collaboration with the Germans or the government of Mussolini's Salò Republic established in September 1943 under the German occupation. ${ }^{41}$

Unlike in Germany, where de-Nazification of music institutions was undertaken by the occupying powers after the end of the war through dedicated offices that also established the rules to be applied, ${ }^{42}$ in Italy a particular program for the de-Fascistization of music was never 
launched. While music institutions were required to apply the general sanctions law, no specific laws or guidelines were issued addressing musicians and the music professions - as were, for example, for journalists and university professors. ${ }^{43}$ Moreover, in contrast to universities, ${ }^{44}$ no directives obliged music institutions to rehire musicians who had lost their jobs for political reasons or as a consequence of the racial laws of 1938 .

At La Scala, board members appointed by the Fascist authorities were arrested or disappeared during the final insurrection of the Resistance. ${ }^{45}$ They included representatives of the Fascist Association of the Performing Arts Industries, the Federation of the Fascist Unions of the Performing Arts, the fascistized municipality, the Ministry of National Education, the National Fascist Union of Musicians (appointed by the Ministry of Corporations), the provincial government, and the Provincial Council of Corporative Economy. ${ }^{46}$ Among the arrested was the Fascist podestà of Milan and president of the board of La Scala, Mario Colombo. As a member of the Fascist city government under the Republic of Salò, Colombo was condemned to death. Eventually, his life was spared, ${ }^{47}$ but he never resumed his role in local government or in the management of La Scala.

On 26 April, the day after the liberation of the city, the CLN designated the Socialist Antonio Greppi as mayor. On 5 May, the CLN city government, on behalf of the national CLN government, appointed the mayor as commissario straordinario (special commissioner) of the municipality's public corporations, including La Scala, with special powers to run them. Among his tasks was oversight of the application of the sanctions. ${ }^{48}$ Greppi's double responsibility as mayor of Milan and commissioner of La Scala made him the key figure in the political transition of the institution. His approach to the transition was determined politically by his long-term loyalty to the Socialist Party, and technically by his legal 
expertise as a criminal lawyer. His anti-Fascist credentials were beyond dispute. As an influential member of the clandestine Socialist Party and as an active anti-Fascist, Greppi had been arrested in 1938 and tried by the Special Tribunal for the Defense of the State. He spent eight months in jail and remained under surveillance until 1943, when he fled Germanoccupied Italy. He returned in 1944 to take part in the armed Resistance. Nevertheless, as a "Catholic in Marxland," as he defined himself, and inspired by Leo Tolstoy's pacifism, his main effort as mayor of liberated Milan was to achieve concord within the community through fairness in the treatment of Fascists. ${ }^{49}$ This humanist element moderated his approach to the sanctions, but the criteria he applied to the purges in the municipality's public corporations still closely reflected the legislation..$^{50}$

According to Greppi's memoirs, the purges dominated life in the city in the aftermath of Liberation, and he was flooded with requests. ${ }^{51}$ The standard practice for noncriminal cases was the referral of Fascist officers, managers, and employees to the Commissions for Purges, which had been established by the CLN within the municipality's public corporations during the insurrectional events of the Liberation, on the basis of specific accusations by the workers' organizations. Accused employees could be temporarily "suspended," substituted, or demoted, and in the most severe cases, immediately dismissed. A “suspended" employee (sospeso) continued to receive a basic salary until final judgement was passed by the relevant tribunal. After that, an individual could be permanently dispensato (dismissed) from office, and in the most severe cases could also lose the right to a pension. At La Scala, members of the orchestra, chorus, ballet, and stage crew appointed an internal CLN commission of three representatives, who voted to suspend eight members of the management and staff, ${ }^{52}$ a small proportion given the number of staff employed at the time (about a hundred employees, plus the orchestra and chorus, and individuals with top managerial and artistic responsibilities). ${ }^{53}$ 
The suspended individuals included Gino Marinuzzi, ${ }^{54}$ resident conductor since 1935, who had been promoted sovrintendente and artistic director by Mussolini himself and on invitation of the German command in January $1945 .{ }^{55}$ By accepting the post, Marinuzzi had collaborated with the German authorities and the government of the Fascist Republic of Salò.

The names of the other seven individuals are not recorded. For all the wealth of archival material preserved at La Scala, documentation of the first few weeks after the final partisan insurgency of 25 April 1945 is rather sparse. Records of the early purging efforts are missing or incomplete, or were later removed. The city archives are equally silent, and there was no press coverage of purges within the institution. However, the season programs suggest that the list may have included, among others, Choral Director Achille Consoli, whose name disappears from the programs of La Scala after Liberation. In December 1939 Consoli had succeeded Vittore Veneziani, who had been dismissed in 1938 as a consequence of racial legislation.

Letters of appeal and subsequent revetting indicate that the group also included the head of stage management, Nicola Benois, as well as four orchestra players and one stagehand manager. ${ }^{56}$ Only in the case of the last individual do we know the reasons for the suspension through his letter of appeal. He had been promoted by the Fascist management from stage worker to a managerial position, and was now accused of having been an informer and of having prevented the distribution of anti-Fascist propaganda materials as well as fund-raising activities in support of the Resistance. He was also said to have threatened workers involved in such activities with dismissal. ${ }^{57}$ In his appeal, he denies having been an informer or spy (even though, in his view, his post might have required just that) or having taken advantage of 
his position to undermine other workers. As with all the early investigations, however, there is no record of a response or of the final resolution.

The AMG officers, who arrived in Milan with the U.S. Fifth Army on 29 April 1945, showed a keen interest in La Scala. Despite the physical destruction of large parts of the city, lack of housing, and limited basic supplies, the AMG decided to help rebuild the theater and, in the meantime, to resume the company's musical activities in alternate venues for the entertainment and morale of the troops and the population. Recognizing the authority of the CLN-appointed mayor of Milan and his city government, ${ }^{58}$ the AMG, together with the CLN, set up a temporary Committee of La Scala. As explained in the American press, the objective was to keep the company operational while the theater building, which had been destroyed by British bombings in August 1943, was being rebuilt, and to guarantee the institution's autonomy from external interference. The committee consisted of five members of the orchestra, the secretary-general of the institution, Luigi Oldani, and two AMG officers. ${ }^{59}$ Oldani's anti-Fascist credentials were apparently not questioned despite his rapid rise under Fascism, which included promotion to head of administration at the age of 26 in 1933 (the year after he had joined the Fascist Party), and to secretary-general at the age of 35 in $1942 .{ }^{60}$ However, promotions awarded on the basis of merit did not fall under the sanctions law, and this may have been perceived to be Oldani's case; moreover, it would have been extremely difficult to replace an experienced staff member in a large institution in which the rest of the management had disappeared or been removed.

The AMG, for its part, was careful to appoint to the temporary committee two individuals with adequate backgrounds. They were Lieutenant Clement Petrillo, a professional pianist who had entered the armed services in 1941, ${ }^{61}$ and Sergeant Hans Busch, a director of opera 
and son of the German conductor Fritz Busch. ${ }^{62}$ It is likely that the idea to appoint the younger Busch had come from Toscanini, whose deep ties with La Scala were well known to the American authorities. Hans's father was a friend of Toscanini who had emigrated from Nazi Germany and, like Toscanini, had eventually set up home in New York.

Because a general purge of singers was expected but had yet to be carried out (in reality it never took place), ${ }^{63}$ the temporary committee decided that in the meantime all who had been accused would have a hearing, and that decisions regarding which singers to engage would be based on considerations of the evidence. However, tenors Beniamino Gigli and Tito Schipa were barred from productions from the start. ${ }^{64}$ Gigli's political record was particularly problematic. His highly publicized participation in a dozen Italian-German film coproductions had been part of the Fascist regime's attempt to promote the bel canto tradition in popular culture. ${ }^{65}$ His concerts in support of the activities of the Fascist Party, as well as his participation in propaganda performances in Germany in $1942,{ }^{66}$ arguably amounted to active participation in Fascist life. And his involvement in performances at the Rome Opera during the German occupation and an official visit to a German command in occupied Northern Italy, publicized through cinema newsreels, ${ }^{67}$ conceivably amounted to collaboration. With the arrival of the Allies in Rome in June 1944, he had been placed under investigation, ${ }^{68}$ and was eventually excluded from productions in the liberated city. ${ }^{69}$ Schipa had been a Fascist, and like Gigli had also been particularly active professionally during the war years, ${ }^{70}$ including in the regime's propaganda initiatives, also publicized through cinema newsreels, ${ }^{71}$ which arguably amounted to active participation in Fascist life.

\section{Revising the Programs}

It is generally accepted that under Mussolini's regime the choice of repertory was informed 
by a nationalist ideology, although that did not eradicate the relatively cosmopolitan character of Italian musical life. ${ }^{72}$ The selection process had tended to favor living Italian composers, and from 1936 the ministry made this tendency the rule, stipulating that a proportion of the works included on programs should be chosen from an official list of operas composed after $1917 .{ }^{73}$ At La Scala, the twenty-three opera and ballet seasons under Fascist rule featured 152 stage works by living Italian composers. ${ }^{74}$ As a policy measure of positive support for contemporary music, this was not an inherently Fascist scheme, but it was not resumed after Liberation, when music by living Italian composers became much less frequent-arguably not only because of box-office considerations at a time of serious financial restraint but also because the scale of the policy must have connoted it as a device intended to secure the consensus of living Italian composers at any artistic or financial cost and not as support for contemporary music per se.

Although official anti-Semitic legislation was not in force until 1938, from early 1934 theater scripts and choreography were subject to systematic censorship on the basis of racial criteria. ${ }^{75}$ Rossini’s Mosè (a favorite at La Scala since 1835) ${ }^{76}$ and Verdi’s Nabucco (which had often been on the program since its première in 1842 and had inaugurated the season on 26 December 1933) were no longer performed at La Scala after 1933 and 1936, respectively. Works by Felix Mendelssohn were not seen on programs after 1933, and compositions by Arnold Schoenberg and Kurt Weill were ignored altogether at La Scala throughout the Fascist period. ${ }^{77}$ The works of other Jewish composers began to disappear systematically from the programs of the music institution soon after the alignment of Mussolini's politics with Nazi Germany: after the 1936-37 season, music by Leone Sinigaglia, Mario Castelnuovo Tedesco, and Ernest Bloch, whose work had previously enjoyed a regular place at La Scala, ${ }^{78}$ was no longer included. Sovrintendente Mataloni was zealous in his interpretation of the racial laws: 
in fall 1938, he ordered Jewish members of the audience to relinquish their season subscriptions, a measure that went beyond the requirements of the law. ${ }^{79}$

Political criteria also affected the programs of La Scala under Fascism. Paul Hindemith's works were no longer performed after 1933, the year in which some of his music was officially banned in Nazi Germany as an expression of "cultural Bolshevism," 80 even if no such ban existed in Fascist Italy. Works by Alban Berg and Anton Webern, excluded in Nazi Germany as "degenerate" art, were not performed at La Scala during this period, even though the Fascist regime had not banned atonal and serial music. ${ }^{81}$ International relations also increasingly dictated program choices under Mussolini. After the imposition of economic sanctions against Italy by the League of Nations in 1935 because of the country's colonial war against Ethiopia, the Ministry of Press and Propaganda ordered that works by Italian composers should replace those by citizens of League countries. At La Scala, Umberto Giordano's Siberia and Francesco Cilea's L'Arlesiana were substituted for Ambroise Thomas's Mignon and Rimski-Korsakov's The Legend of the Invisible City of Kitezh and the Maiden Fevroniya. ${ }^{82}$ At the beginning of World War II, the Ministry of Popular Culture introduced a systematic ban on works by living composers belonging to enemy nations, and recommended performers and living composers belonging to the German ally. ${ }^{83}$

After Liberation, revisions to the programs of La Scala had to comply with the AMG's request that the company resume its performances in alternate venues as soon as possible. ${ }^{84}$ Because new opera productions would have required lengthy preparations, the solution was a partial continuation of the existing season in combination with newly organized concerts. To appease the public and preempt complaints about using casts previously engaged by the Fascist management, the temporary committee of La Scala declared the season formally over 
and announced a new series of concerts that included four operas from the current seasonPuccini's La Bohème, Stravinsky's Mavra, Giorgio Federico Ghedini's La pulce d'oro (1940), and Ponchielli's La gioconda - to be performed at the Teatro Lirico and in the courtyard of the Castello Sforzesco beginning 9 May. On the mayor's initiative, the public was also informed that even though the four operas had to be performed by singers already under contract, the purging of vocal artists would go ahead as planned. ${ }^{85}$

The concert programs reintroduced the national repertoires banned during the war and the work of composers excluded under Fascism for racial and political reasons. The first concert, which was conducted by Antonino Votto on 9 May at the Teatro Lirico "in honor of the Allied Troops present in Milan and the Italian Patriots," 86 included Mendelssohn's Scherzo from A Midsummer Night's Dream. The other concerts of that season included Mendelssohn's Hebrides Overture ("Fingalshöhle"), Op. 26, and Symphony No. 4 ("Italian”), as well as Sinigaglia's Overture to Le baruffe chiozzotte, Op. 32 (1907-8); Bloch's Concerto Grosso for Strings and Piano Obbligato (1925); Hindemith's symphony Mathis der Maler (1934); a great deal of French and Russian music, including the first Italian performance of Dmitry Shostakovich's suite from the ballet Zolotoy vek (The Golden Age), Op. 22a (1930); Samuel Barber's Adagio for Strings (1936); and Jazz Music (1933) by the Belgian composer Marcel Poot, which marked a reversal of the ban and general distrust of jazz as American and "Negro" music, particularly since the mid-1930s. ${ }^{87}$

Also to be addressed was the question of whether to include works by composers whose political record was heavily compromised, and Greppi insisted that it was necessary to remove any Fascist "residues" from existing programs and reintroduce works that had been excluded by the Fascist or German authorities. ${ }^{88}$ A production of the choreographic 
divertimento Mondo tondo (1943) by Ennio Porrino was taken off programs, ${ }^{89}$ on grounds that it had been included on the recommendation of the Ministry of Popular Culture of the Salò Republic, where Porrino had been employed to compose music for propaganda films. ${ }^{90}$ Despite insistence by the publisher Ricordi that pre-Liberation agreements needed to be fulfilled, Greppi stood firm. ${ }^{91}$ Porrino had been purged after the first fall of Mussolini, but had remained an open supporter of Fascism even after 1943 and an active and public defender of "Italianness" against "internationalism" and "Judaism" in music. He had even composed the anthem "Marcia del volontario" for the Salò Republic. ${ }^{92}$

The parties of the Left did not have clear plans for the direction of cultural and artistic matters after Liberation. In 1943, the Socialists had agreed with the Communists on a pact of unity of action against Fascism, ${ }^{93}$ and their politics had become subordinated to that of the Communists. ${ }^{94}$ However, the Communists did not formulate a clear cultural policy for two years after Liberation — in part because their workerist and anti-intellectualist constituent distrusted and opposed any cultural activities, and in part because the cultural focus of their leader, Palmiro Togliatti, was on the recruitment, ideological reorientation, and mobilization of intellectuals. ${ }^{95}$ In the absence of an official cultural policy of the Socialist Party, Greppi's ideas for the role of La Scala in post-Liberation society were arguably inspired by the traditions of cultural initiatives of municipal socialism, which had flourished in Milan under the Socialist-led city administrations in the years before Mussolini's rise to power. Greppi could also count on his own experience as a prolific amateur playwright and novelist who used his plays to show the pursuit of socialism through the search for ethical meaning in everyday life..$^{96}$

Whereas the AMG enforced a rigorous separation of music and politics in the American- 
occupied sectors of Germany, ${ }^{97}$ there is no evidence of an equivalent concern at La Scala. On the contrary, through a series of initiatives realized in collaboration with the AMG, Greppi mobilized the orchestra and chorus as resources for the expression of political and ethical anti-Fascist and Resistance values. On 19 May 1945, a string quartet from the La Scala orchestra performed a concert sponsored by two CLN-based organizations, the Groups for the Defense of Women (Gruppi di Difesa della Donna) and the Youth Front (Fronte della Gioventù), to mark the conclusion of a week of national solidarity in support of former deportees, partisans, and the families of victims of political repression..$^{98}$ On 24 May, a performance of excerpts from Verdi's Requiem in the Galleria Vittorio Emanuele paid tribute to sixty-seven political prisoners who had been massacred by the Germans in collaboration with Fascist authorities in July 1944 at the infamous Fossoli police and transit camp. On 10 June, the first public commemoration of the Socialist M.P. Giacomo Matteotti, who had been murdered in 1924 by Fascist assassins, was accompanied by a performance of the anthems of the allied nations and of Beethoven's "Eroica" Symphony at the Teatro Lirico. ${ }^{99}$ President Roosevelt, who had died two months earlier, and the "Caduti della Libertà" (Those Fallen for Freedom) were celebrated on 19 June at the Teatro Lirico with a performance of Verdi's Requiem conducted by Tullio Serafin, with singers Margherita Grandi, Ebe Stignani, Emilio Renzi, and Tancredi Pasero, and with officers of the Allied Army and numerous diplomats present. ${ }^{100}$ Greppi, as mayor of Milan, and the AMG governor for Lombardy, Charles Poletti, gave speeches that celebrated Roosevelt's anti-Fascism and the Italian Resistance. ${ }^{101}$ Poletti was the son of Italian immigrants and, like Greppi, a lawyer and politician. A man of the American Democratic establishment, he was an anti-Fascist who had a genuine interest in the democratic rebirth of Italy. ${ }^{102}$ His political career had developed in Roosevelt's New Deal America, where the arts had been given a prominent social role through initiatives such as the Federal Art Project of the Works Progress Administration. 


\section{Managerial and Artistic Appointments}

The question of revising the organizational structure of La Scala was initially not considered urgent by Greppi. It became a priority, however, when on 1 June 1945 the AMG ruled that any deliberations by agencies of the CLN no longer had legal validity and were to be replaced by AMG decrees and orders; CLN agencies within the local administrations would be downgraded to have technical and consultative functions only; and CLN agencies at workplaces would need to be transformed into trade unions or technical bodies. ${ }^{103}$ In this situation, Greppi would have to constitute a new board and seek its approval by the AMG to retain control of the institution. This apparently simple task was burdened with several difficulties. A key problem was that the new board would need to be established in compliance with the rules of the Fascist statute, which was still in force. Even though Greppi had the authority to modify the statute, ${ }^{104}$ he decided to reorganize the institution in an alternative way, without waiting out the lengthy process of drawing up and approving the amended statute. At the same time, no legal mechanism existed for appointing a new sovrintendente. Because of the dissolution of the Ministry of Popular Culture in 1944, there was no official body to legitimize the appointment as required by the law of 1936, which also was still in force.

On the other hand, on the basis of this same 1936 legislation, the mayor, who had replaced the Fascist podestà, had assumed the role of president of La Scala and could try to appoint a new special commissioner. However, he did not succeed at first, ${ }^{105}$ possibly because of disagreements with the CLN government on his proposed candidate, or because the AMG did not grant its approval. He therefore went on to form a new commissione tecnicoamministrativa (technical-administrative commission), which was approved by the AMG as a 
substitute for the board of directors and which was authorized to handle the program, the budget, and the reconstruction of the theater. ${ }^{106}$ In addition to Greppi and Secretary-General Luigi Oldani, the commission included six staff members with responsibilities in different areas of production. These staff members were artistic coordinator and conductor Giuseppe Del Campo; orchestra musician Enrico Tabanelli; choral director Veneziani; tenor Aureliano Pertile; Ettorina Mazzucchelli, head of the ballet school; and stage director Mario Frigerio. Veneziani, at the time still in Switzerland, where he had emigrated after introduction of the racial laws, was appointed in absentia. The commission was integrated with the offices of Petrillo and Busch, who now were referred to as staff of the Ufficio Opera e Concerti of the AMG. ${ }^{107}$

As an alternative to his original plan to appoint a special commissioner, Greppi proposed to the AMG the appointment of an administrative consultant who would be part of the commission, ${ }^{108}$ his intention arguably being to appoint this person special commissioner as soon as technically possible. For this role, Greppi proposed Antonio Ghiringhelli, another long-term member of the Socialist Party. ${ }^{109}$ In 1930, as a young economics graduate working for a company of management consultants, Ghiringhelli had been given temporary responsibility as auditor at La Scala, with the additional task of reorganizing its administrative structure. His knowledge of the theater was therefore quite thorough. He had no musical expertise, but the plan was to appoint an artistic director who would assist him with artistic matters. ${ }^{110}$ In contrast to the Fascist policy of concentrating managerial and artistic responsibilities in a single person, La Scala now returned to the separation of artistic from managerial responsibilities that had been put in place with the creation of the ente autonomo in $1920-21$. 
One of the main issues discussed at the first meeting of this commission on 25 June 1945 was the return of Toscanini and Veneziani. It was assumed that both would resume their previous roles and that Toscanini would conduct the inaugural concert in the rebuilt theater. ${ }^{111}$ However, only Veneziani returned and took up his post on the commission on 23 July $1945,{ }^{112}$ immediately securing an agreement that the chorus would be enlarged and that any members recruited during his absence would be auditioned again, together with any potential new members. ${ }^{113}$ After Veneziani's dismissal, the quality of the chorus had declined so rapidly and dramatically that in 1939, in response to stark and persistent criticism by music critics and audiences, sovrintendente Mataloni dismissed over forty choristers and recruited new singers. ${ }^{114}$ The auditions may have now given Veneziani the opportunity to rehire some chorus members who had lost their jobs because of racial legislation and political bias, and to test the professional skills of any members recruited during Mataloni's restructuring. The enlarged chorus was engaged by 15 October and began to rehearse the following month. ${ }^{115} \mathrm{~A}$ concert was scheduled for 28 November and officially announced as a celebration of Veneziani's return. Together with works by Palestrina and Debussy and the premiere of Ildebrando Pizzetti's "Cade la sera," the program also included transcriptions of folk songs from the Italian regions that had been in the repertory of Veneziani's chorus in the 1930s. Fascism had promoted folklore as a unifying nationalist device ${ }^{116}$ but was hardly unique in promoting this kind of repertory. The revival had been part of folklore studies in Italy since the nineteenth century. ${ }^{117}$

There is no record of any actions to encourage and facilitate the return of orchestra players who had lost their jobs during the Fascist regime. According to Sachs, it was only at Toscanini’s request in April 1946 that Jewish musicians and political opponents were recruited to rejoin the La Scala orchestra, ${ }^{118}$ but in the archives of La Scala there seems to be 
no evidence to either confirm or deny such a claim. At the time, orchestra players were hired by the season, and it is possible that even without purposeful action some Jewish staff members and political opponents who were still alive would have been reintegrated in the orchestra through the seasonal recruitment process.

Politically suitable guest artists were generally selected by the AMG, and Busch assisted Petrillo by keeping in direct contact with Toscanini in New York. ${ }^{19}$ Securing high-profile artists not discredited by collaboration with the Salò Republic or the Nazi authorities was a difficult task, and the Americans were aware that in the capital of the Resistance, criteria identifying collaborators were more stringent than anywhere else in the country, and locals fiercely opposed any concessions. ${ }^{120}$

Busch and Petrillo also supervised the selection process for important artistic appointments. In July 1945, Lieutenant Petrillo took the lead on the appointment of an artistic director, proposing a list of four names, although he clarified that the final decision would be subject to Toscanini's approval. His candidates were Bernardino Molinari, Antonio Guarnieri, Tullio Serafin, and Victor De Sabata. ${ }^{121}$ The list was certainly not markedly anti-Fascist, and consequently, as a journalist for the New York Times reported from Milan, any choice was "bound to stir up the bees." ${ }^{122}$ All four conductors had been associated with La Scala well before the rise of Fascism, but three had done more than just continue to conduct under the Fascist regime. De Sabata, who in the 1930s replaced Toscanini as principal conductor, frequently conducted in Nazi Germany, notably during the La Scala tour of 1937—a highly symbolic initiative in cultural diplomacy that was designed to demonstrate the growing closeness of Fascist Italy with Nazi Germany. ${ }^{123} \mathrm{He}$ also conducted the company during its appearance at the Bayreuth Festival in 1939. ${ }^{124}$ Molinari, too, toured Nazi Germany in the 
context of the highly publicized cultural exchanges of the Axis powers in 1940-41, and secured a permanent venue for the Santa Cecilia Academy Orchestra at the Teatro Augusteo in Rome through the personal support of Mussolini. In his role as a member of the Direttorio of the National Fascist Union of Musicians, he acted informally as Mussolini's music consultant. ${ }^{125} \mathrm{He}$ also conducted at official events of the regime. ${ }^{126}$ In June and July 1944 , after the liberation of Rome, such past circumstances led to protests on the part of audiences, orchestra performers, and one singer, and as a result he was banned from performances. ${ }^{127}$ Serafin, the third candidate, had been appointed artistic director of Rome's Teatro Reale by the Duce himself. ${ }^{128}$

The artistic preference of the Italian members of the commission was for Serafin. ${ }^{129}$ However, Greppi insisted that the conductor's political record should be subject to further careful examination, and for this purpose, he set up a special commission. ${ }^{130}$ Serafin had already conducted some post-Liberation concerts at La Scala, but for the post of artistic director a more rigorous vetting was necessary. In the meantime, the post was entrusted to Mario Rossi, who had been resident conductor at the Maggio Musicale in Florence from 1937 to $1944 .{ }^{131}$ No material documenting the results of the assessment of Serafin's political record have been preserved, but he was eventually appointed, and the news was published in the Corriere d'Informazione on 11-12 September 1946. We now know that Serafin was one of the few established Italian conductors - others being Fernando Previtali and Vittorio Gui, for example—who never joined the Fascist Party. ${ }^{132}$

The AMG's decision to downgrade the role of the CLN and its agencies to technical and consultative functions generated questions about the legal status of the earlier CLN commission at La Scala and the legitimacy of the purges it had administered; two of the four 
suspended orchestra players requested reinstatement by appealing to the AMG. Greppi asked for an examination of the political records of the two players before a decision was made, and the AMG did not object. ${ }^{133}$ Here, too, there is nothing in the archives to document the investigative findings. That orchestra players were considered under the rubric of workers may have been taken into account, in line with CLN guidelines recommending firmness in judging Fascists who had been in positions of command and indulgence in judging those in the lower ranks of society, who might have supported Fascism out of delusion, weakness, or even deception. ${ }^{134}$ However, one of the players, accused of having been a member of the Fascist squads and later of the Fascist Republican Guard, was suspended until 6 June 1946, when a special commission for formalizing the purges of Fascist staff at La Scala was formed to issue a verdict by the final deadline of 30 June. The dismissal was not confirmed, however. The law had changed in the meantime and now excluded membership in the Fascist squads from the list of reasons for dismissal. Moreover, the orchestra palyers seems to have submitted proof confirming that, although he had been called up to join the Fascist Republican Guard, he had sought an exemption and eventually succeeded. ${ }^{135}$

With a technical-administrative commission in place that included a high proportion of artistic staff, greater attention was now put on the reconciliation of politics and artistic considerations in the application of the law. In August 1945, Ghiringhelli and Frigerio suggested that the political record of Nicola Benois, the painter and stage designer who had earlier been suspended, should be re-examined from an artistic point of view, and Greppi himself interviewed him. ${ }^{136}$ The decision of the CLN commission to suspend Benois seems to have been overthrown: he was reinstated to his position.

In some cases, however, even great artistic prestige could not redeem a compromised political 
record. On 2 August 1945, news of composer Pietro Mascagni's death required the commission to make a difficult decision as to what official steps La Scala would take to honor his memory. Mascagni's works had been banned in liberated Rome in $1944,{ }^{137}$ but the law did not provide guidance on how to deal with the memory of prominent Fascist figures who had died after the fall of Fascism. Choral director Veneziani and stage director Frigerio suggested sending a telegram to the family, worded in such a way that it would honor the artist but not the man. Greppi rejected the proposal, ${ }^{138}$ his motivation being that the composer had conducted in the uniform of the Fascist Party on several occasions, ${ }^{139}$ arguably amounting to what the law considered active participation in Fascist life. Mascagni had been particularly active, conducting concerts for the Opera Nazionale Dopolavoro (OND; an organization that provided mass leisure activities) and the Federazione Fascista dell'Urbe in Rome, ${ }^{140}$ and operas for one of the regime's flagship musical initiatives, the Carro di Tespi Lirico, which toured the provinces.

The composer had also received unparalleled honors and privileges. He was made a member of the Accademia d'Italia, the most important cultural institution in Mussolini's Italy, at its founding in 1929, and in 1934, two years after officially becoming a member of the Fascist Party, he was appointed the academy's deputy president. ${ }^{141} \mathrm{He}$ conducted the premiere of his last opera, Nerone (1935), at La Scala on Mussolini's invitation and with his backing. The opera was promoted with such excessive publicity that the first night became one of the most sumptuous musical events in the history of the Fascist regime. ${ }^{142}$ The fiftieth anniversary of the premiere of Mascagni's Cavalleria rusticana was celebrated throughout Italy in 1940, supported by the massive publicity generated by the regime's propaganda machine. ${ }^{143}$ Finally, Mascagni had continued to offer enthusiastic support to Mussolini even during the war years. ${ }^{144}$ Despite his standing and popularity, which under normal circumstances would have 
justified a special commemoration at his death, Mascagni's operas, which under Fascism had been the most frequently performed of any living Italian composer at La Scala, were not included in the company's post-Liberation season at the Teatro Lirico.

However, that season included works by other compromised composers, though they were arguably less compromised than Mascagni. The works were Giordano's Andrea Chénier (conducted by the composer in celebration of the fiftieth anniversary of its premiere), Cilea's Adriana Lecouvreur (1902), and Riccardo Zandonai's Francesca da Rimini (1914), which opened the season in memoriam of the recently deceased composer. ${ }^{145}$ Like Mascagni, Giordano had been a member of the Accademia d'Italia since 1929. He had also composed two works in honor of the regime: in 1932, on Mussolini's decree, the Inno del Decennale to celebrate the tenth anniversary of the Fascist seizure of power, and in 1936, the Inno imperiale to celebrate Mussolini's imperial ambitions. ${ }^{146}$ Cilea had been appointed a member of the Accademia d'Italia in $1938,{ }^{147}$ and Zandonai had been a member of the Direttorio of the National Fascist Union of Musicians. ${ }^{148}$ Giordano and Cilea, like Mascagni, had also been in active correspondence with the Duce, a circumstance that was hardly known publicly at the time and arguably did not in itself constitute a reason for purging. Ultimately, these artists had accepted, harnessed, and repaid the regime's flattery, but they had not been zealous supporters, especially after 1943.

\section{Politics and Performance: Toscanini's Inaugural Concert}

The celebration of anti-Fascist values continued in the fall of 1945 at the Teatro Lirico with the first La Scala performance of Shostakovich's “Leningrad” Symphony (1941), a work inspired by anti-Nazi sentiment and famously composed and first performed during the German siege of that city. Detailed information emphasizing the political significance of the 
work and the fact that it had already been performed in America by Toscanini was attached to the press releases announcing the event. ${ }^{149}$

Reconstruction of the theater building was meanwhile under way, and Mayor Greppi, who considered La Scala highly symbolic of the city's rebirth after Fascism and the war, ${ }^{150}$ undoubtedly wanted the work completed before the local elections of March-April 1946. Once confirmed as mayor in the local elections - in which the Socialists, with 36 percent of the vote, became the leading political party ${ }^{151}$ — he finalized the details for the inaugural concert of La Scala, scheduled for 11 May. The performance was to be conducted by Toscanini, a musical icon of anti-Fascism, with representatives of the National Liberation Committee and foreign governments in attendance. Greppi intended to open the event with a brief speech commemorating the Resistance. His Socialist candidacy in the forthcoming Constituent Assembly elections on 2 June, ${ }^{152}$ together with his role as mayor of Milan, called for a clear position on Italy's Fascist past. Reopening La Scala without a strong statement on the struggle for democracy was simply unthinkable.

Political developments at the national level, however, gave Greppi's plan a somewhat new motivation. The victory of the Left in Milan's local elections was in marked contrast to developments in the national government. From fall 1945 on, the propagation of antiCommunism by the conservative press had undermined the political cohesion within the CLN national government coalition, and in November, the Christian Democrats and the Liberals had forced the CLN-appointed prime minister, Ferruccio Parri, whom they considered too radical, to resign. In the northern provinces, which the AMG had restored to the Italian government on 1 January 1946, Parri’s successor, the Christian Democrat Alcide De Gasperi, replaced almost all of the CLN-appointed prefects (one of the exceptions being the prefect of 
Milan) with career civil servants of his own choice. ${ }^{153}$ In this changed scenario, the Socialist mayor's goal now was to make sure that the heroes and martyrs who had fallen for freedom would not be forgotten. ${ }^{154}$

Toscanini, who arrived in Italy in April for rehearsals, put a firm veto on the address, however. His decision remained unshakable and nonnegotiable, and the mayor decided not to attend the inaugural concert. ${ }^{155}$ The incident was not made public, but it is indicative of the political tensions at the time and the relationship between a particular performance and the politics of the time.

Jane Fulcher has argued that in order to understand the relationship of music and politics in "politically transitional epochs, ... where repertoires were intended to be performative, to say and do something beyond their content," we need to take into account the "communicative totality of performance, consisting of content, context, and means of transmission," in which "the audience 'constructs' interpretation through frames which can be mediated, amended, or manipulated" by means of a "politically significant text" and "the shaping of performative ambience" which constitute "keys" that "create a politicized interpretive frame". ${ }^{156}$ The musical celebrations Greppi had organized with the AMG in 1945 offered precisely such an interpretive framing to promote the values of anti-Fascism, and he clearly wished to do the same with the inaugural concert—especially as the event was a much more significant occasion musically, culturally, and politically.

On the other hand, Toscanini likely was conscious of the political sensitivities of the Truman administration, as he had reassured the American press that his visit to Italy to conduct the inaugural concert was in no way political: he was returning "for purely sentimental 
reasons." 157 The Allies, already concerned about the presence of the Communists and Socialists in the CLN national coalition government, ${ }^{158}$ were undoubtedly apprehensive about the upcoming general elections for the Constituent Assembly and for the referendum in which Italians would choose between monarchy and a republic. The La Scala concert, scheduled only three weeks before the referendum and the elections, was a national and international event, broadcast live on Italian radio and relayed to Britain, France, Switzerland, and, via shortwave, the rest of the world. ${ }^{159}$ A Socialist mayor celebrating the Resistance, in which the Communist Party had played a prominent role, not only threatened to contribute locally to the further radicalizing of public opinion on the eve of the popular vote but would also have delivered a problematic political message abroad.

Yet Toscanini was not a man used to bowing to political authorities, including the Americans. In 1944, he and other Italian exiles had signed an editorial in Life magazine that was strongly critical of Allied policy in Italy, and particularly of what Toscanini believed to be its aim: the consolidation of a conservative-authoritarian government under the Savoy monarchy, a "Fascism without Mussolini." ${ }^{60}$ It is therefore unlikely that he would have been accommodating toward external political influences - not because he believed in an idealist separation of music and politics (on the contrary, since World War I he had done the opposite) ${ }^{161}$ but because he had always determined the political motives of his own performances. But in this case, those motives were not explicit.

Sachs has suggested that the conductor intended to support the republican cause at the referendum. ${ }^{162}$ Toscanini was indeed an impassioned antimonarchist; he abhorred the Royal House of Savoy and had initially been reluctant to return to Italy while the "degenerate King . .. who gave to the Fascists tyranny material and moral support" was still officially in 
power. ${ }^{163}$ He therefore did not approve of the political compromise the CLN had made by agreeing to form a government under the monarchy. Only after the announcement in midMarch 1946 of a referendum on 2 June had he finally resolved to return to conduct the inaugural concert at La Scala. ${ }^{164}$ Yet Toscanini's political ideology was broader than his antimonarchical stance, ${ }^{165}$ and the music he chose for the concert offers no evidence of support for the republican vote. On the surface, the program was simply a selection of excerpts, almost all operatic, from works by Italian composers. The first part included the overture from Rossini's La gazza ladra; the wedding chorus and "Passo a sei" dances from act 1 and the Soldiers' Dance from act 3 of Rossini's Guglielmo Tell; the aria-prayer "Dal tuo stellato soglio" that Rossini had added to his Mosè in Egitto for the Naples revival of 1819; the overture and "Va, pensiero" from Verdi's Nabucco; and the overture from Verdi's I vespri siciliani. The second part of the program opened with the Te Deum from Verdi's Quattro pezzi sacri (1898), followed by the Intermezzo and third act from Puccini's Manon Lescaut and the Prologue from Boito's Mefistofele. ${ }^{166}$

These works were all dear to Toscanini and were carefully chosen for this event. In addition, some had symbolic links to La Scala and the city of Milan: Rossini's La gazza ladra and Verdi's Nabucco had premiered at La Scala, while the text of Verdi's Te Deum was an early Christian hymn of thanksgiving that was sung on important occasions, including military victories; it was believed that St. Ambrose, the patron saint of Milan, had contributed to the text. ${ }^{167}$ The Prologue of Boito's Mefistofele can be seen as a warning against the corrupting power of evil and the weakness of the human will.

However, most important were the themes of patriotism and exile, and of the plight of the Jewish people: in Guglielmo Tell, a conspirator in the Swiss homeland oppressed by a 
tyrannical Austrian governor; in Verdi's I vespri siciliani, the insurrection of the Sicilian people against the French occupation in 1282; in "Dal tuo stellato soglio," Moses leads the exiled Hebrews" prayer for freedom; and "Va, pensiero" gives expression to the Jewish people's nostalgia for their oppressed homeland. "Va, pensiero" and the overture from $I$ vespri siciliani had featured in patriotic programs in Italy since the end of the nineteenth century and particularly during World War I, ${ }^{168}$ which tended to foreground Italian operas with a history of association with the ideals of the Risorgimento, the nineteenth-century movement for Italian unification. ${ }^{169}$ Toscanini himself had often conducted such programs. ${ }^{170}$ After World War I, the ideological meaning associated with these works had shifted from patriotism to nationalism, and Toscanini had famously performed the overture from I vespri siciliani with the La Scala orchestra at ultranationalist celebrations in Fiume. ${ }^{171}$ Under the Fascist regime, "Va, pensiero" and "Dal tuo stellato soglio" were included in the official Canzoniere nazionale (National Songbook) that was made compulsory for all schools in $1929,{ }^{172}$ although both works would be banned a few years later because of their Jewish subject. Nationalism, however, was not a Fascist preserve. Beginning in 1944, the Italian Communist Party made it an important feature of its own ideology, in order to counter its image as an internationalist entity aligned with the Soviet Union and cement its reputation as a national party, and thereby achieve legitimacy and acceptance within the new democratic political life. ${ }^{173}$

Toscanini's program was therefore compatible with the promotion of the Resistance as the "second Risorgimento of Italy," as it was called by those CLN parties that were (or aspired to be) heirs of the national Risorgimento tradition, and an explicit commemoration of the Resistance along Greppi's lines would not have added interpretive "keys". A speech may not have been needed, but it is possible to argue that it could have posed a problem for Toscanini. 
The Resistance had brought together anti-Fascists holding a wide range of ideological positions, including that of the monarchists. An explicit commemoration of the Resistance could have opened the ideological frame of the concert to monarchical positions because it would have given monarchists the opportunity to offer explanations for the program in the press. We can therefore assume that Toscanini intended the concert as a contribution of La Scala to the promotion of anti-Fascist values, though in a more radical, antimonarchical form than could have been done through a framing speech by Greppi.

It is of course difficult to estimate how many of those in the theater, or listening to broadcasts of the concert in the squares of the city or on the radio, understood this, and how effective the concert was in mobilizing music making for political change. Ironically, it was perhaps the Fascist regime's propaganda, through which it had disseminated the musical manifestations of its nationalist-patriotic ideology to a broad segment of the population, that Toscanini could rely on to make some of the implied ideological position clear.

Inevitably, the vast majority of musicians, organizers, and audiences who had supported, benefited from, or at minimum tolerated Fascism continued to participate in musical production and life after Liberation. Nonetheless, as a consequence of systemic change brought about by the new political-institutional system, they could now do so only within the limits of a democratic and pluralist organization of musical production and life. Many of the historical continuities in the organization of music did not involve inherently Fascist phenomena. The persistence of the 1936 performing arts legislation, which regulated the life of music institutions, continued a centralized approach to music policy and retained an 
element of corporative labor relations, but as a consequence of the suppression and dissolution of the agencies of the regime on which the Fascist character of the law had depended, it was compatible with a pluralist and democratic organization of music.

Adherence to some of the historical continuities produced change. The close relationship between local governments and music institutions inscribed in the 1936 legislation continued, and at La Scala, it resulted in a Socialist takeover.

The Fascist-appointed board of La Scala was dissolved and the sanctions law applied, with the Fascist staff subjected to purges. Invitations to guest artists were carefully filtered, and candidates for important artistic appointments had to undergo a rigorous vetting process. Decisions were made based on thorough investigation and discussion while trying to balance rigor with fairness. And though some motivations for rigor or leniency are not justifiable today, they seem to have made sense on the basis of the information available at the time.

The sanctions law did not punish compliance with the racial legislation or provide restitution or compensation for musicians who had been the victims of Fascism. At La Scala, however, steps were undertaken to secure the return of the director of the chorus, Veneziani, immediately after Liberation. The management also supported Veneziani's request to audition and enlarge the chorus, possibly providing an opportunity for re-engagement to members who had lost their jobs because of the racial legislation or for political reasons. On the other hand, there is no evidence of purposeful action to facilitate the return of Jewish or politically excluded orchestra players before the inaugural concert of May 1946. Yet, because orchestra players were recruited seasonally, it is also possible that musicians who had lost their jobs for racial and political reasons may have been re-recruited through normal channels. 
The programs of La Scala were revised to eliminate the ultranationalist, racial, and political biases that had been introduced in the repertory under Fascism. The institution was also involved in events aimed at the promotion of anti-Fascist values, showing that the relationship between anti-Fascist politics and music, overlooked by the continuity argument, was in fact present.

I hope to have shown in this article that the continuity argument needs to be qualified by excluding phenomena that were not intrinsically Fascist, and that it needs to pay greater attention to systemic consequences of political-institutional change as well as to purposeful actions aimed at change. However, I have concentrated only on the first year after Liberation, during which the sanctions against Fascist organizations and individuals were in force. A long-term study of La Scala after the first amnesty of 22 June 1946 could ascertain the effects of the amnesties, which freed almost all Fascists from Italian prisons between 1946 and 1953, as well as the implications of the return of the staff of the Theater Inspectorate to the ministerial bureaucracies in 1948. Although Fascist objectives and methods are likely to have been significantly limited through the closing of Fascist agencies that had supported the work of the Inspectorate under Fascism, specific empirical research would be necessary to gauge the Fascist character of the objectives and achievements of its former staff in the postwar period. Such an analysis could also assess the impact of the relationship of music institutions with the state more generally, including with state agencies on which musical production came to depend, such as the Ministry of Tourism and Performing Arts established in 1959, when continuities with Fascism within Italian state offices and the general legislation were far from exhausted. It may also help our understanding of the effects of international trends such as the exoneration of musicians accused of having been Nazi sympathizers and their reintroduction into international music circuits. 


\begin{abstract}
Notes
Paola Merli is assistant professor in cultural studies at the University of Nottingham. Her current research interests are in the history of music policy and institutions.

\section{E-mail: paola.merli@nottingham.ac.uk}

I wish to thank Ben Earle and two anonymous referees for their detailed comments on earlier drafts of this article, and Irene Piazzoni and Robert Adlington for their helpful advice. I am grateful to the management and staff of La Scala, who granted me access to the archives of the music institution, and to Jeff Hill, Tim O’Sullivan, Richard Johnson and Steve Chibnall for their help in the early stages of development of this research project.

${ }^{1}$ See, for example, "Le malefatte del fascismo nel campo musicale," Rivista Musicale Italiana 48 (1946): 67-87. This was a reprint, with introductory comments, of a memo sent by a group of old conservatory teachers to Education Minister Guido De Ruggiero, a member of the Action Party who held office from 18 June to 10 December 1944 in the government of the liberated South. The memo discussed the consequences of the lowering of moral standards in the recruitment of teaching staff under the Fascist regime and of the opportunistic behavior of the musicians sitting on the commission, which had been set up in 1941 to pursue national self-sufficiency (autarchia) in teaching curricula and textbooks.

${ }^{2}$ Pioneering works were, for example, Luigi Pestalozza's extensive "Introduction" to the collection La rassegna musicale: Antologia (Milan: Feltrinelli, 1966), ix-clxxviii, which consisted of an edited selection of texts published by the journal La Rassegna Musicale from 1928 to 1943, with an appendix of articles from Il Pianoforte from the period 1921-26; and 
Rubens Tedeschi’s “La musica negli anni del Fascismo," in Arte e Fascismo in Italia e in Germania, ed. Enrico Crispolti, Berthold Hintz, and Zeno Birolli (Milan: Feltrinelli, 1974), 176-81. Also in general historiography, "it was only in the 1960s that academic historians began to turn their attention to Fascism," while "in the realm of 'popular' history . . . the decade of the 1950s was marked by a profound silence about the failures, delusions and terrors of Fascism. After all, this was the era not of anti-Fascism but of anti-Communism, and any hint of a critical reading of Mussolini's rule could be attacked by the anti-Communist media as insulting the war dead and 'outraging' the patria." R. J. B Bosworth, The Italian Dictatorship: Problems and Perspectives in the Interpretation of Mussolini and Fascism (London: Arnold, 1998), 108 and 109-10.

${ }^{3}$ Piero Santi, “La musica del fascismo," Musica/Realtà 2, no. 4 (1981): 95-103. Santi focused on the case of musical modernism, noting that in scholarship modernist composers were portrayed as independent of Fascist politics and given a progressive significance in an assumed regressive historical context allegedly dominated by naturalist opera. In so doing, he argued, the existence of Fascism as the actual historical context for the activities of those composers was denied, reinforcing a prejudice and endorsing a major gap in the study of Italian music in the twentieth century. The mediation of a highly regulatory state and its multitude of technocrats, Santi claimed, gave modernist composers the possibility of pursuing a style that ignored both audience taste and the mechanisms of market competition that had constituted the social and economic context of naturalist opera. In fact, he concluded, the cultural program of modernist composers had simply been part of the political program of Fascist leaders who wanted to move the nation away from what they saw as the provincialism of pre-Fascist Liberal Italy. 
${ }^{4}$ On Pestalozza's role within the Party, see his interview with Claus-Steffen Mahnkopf, “Gespräch mit Luigi Pestalozza: Resistenza und die Frage des 'Ungehorsams,'” Musik und Ästhetik, 7, no. 26 (2003): 91-101.

${ }^{5}$ Luigi Pestalozza, “Lo Stato dell'organizzazione musicale: La svolta del fascismo e la sua lunga durata," Musica/Realtà 2, no. 5 (August 1981): 143-60.

${ }^{6}$ Pestalozza, "Lo Stato dell'organizzazione musicale."

${ }^{7}$ Fiamma Nicolodi, Musica e musicisti nel ventennio fascista (Fiesole: Discanto, 1984), passim.

${ }^{8}$ Fiamma Nicolodi, “Opera Production from Italian Unification to the Present," in The History of Italian Opera, ed. Lorenzo Bianconi and Giorgio Pestelli, vol. 4, part 2, Opera Production and Its Resources: Systems (Chicago: University of Chicago Press, 1998), 165-228, here 192-207; originally published as "Il sistema produttivo, dall'Unità a oggi," in Storia dell'opera italiana, ed. Lorenzo Bianconi and Giorgio Pestelli, vol. 4, Il sistema produttivo e le sue competenze (Turin: EDT, 1987), 167-229.

${ }^{9}$ Nicolodi, “Opera Production,” 210, 218, 209.

${ }^{10}$ Guido Salvetti, "Politica, cultura, musica," introduction to Italia millenovecentocinquanta, ed. Guido Salvetti and Bianca Maria Antolini (Milan: Guerini, 1998), 13-28. One of the investigators later specified that the post-Liberation continuity was with arrangements dating to the early 1930s. Marcello Ruggieri, "Lo stato e le organizzazioni musicali. Tra 'rappresentanza' e 'governo degli interessi' (1926-1948),' Nuova Rivista Musicale Italiana 3 (2000): 415-41.

${ }^{11}$ Harvey Sachs, "La Scala durante il ventennio fascista," Nuova Rivista Musicale Italiana 23, nos. 1-2 (1989): 99-111.

${ }^{12}$ Luisa Zanoncelli, "La politica culturale della Scala," in Milano anni cinquanta, ed. 
Gianfranco Petrillo and Adolfo Scalpelli (Milan: Franco Angeli, 1986), 779-827.

${ }^{13}$ The argument is indebted to the historiographic thesis of the "continuity of the state." For the historian Claudio Pavone, a leading proponent of the thesis in the mid-1970s, the Fascist state, far from being a deviation from the Liberal one, had strengthened the trends toward a larger role for the state in social and economic life and greater centralization. Such trends, which Pavone considered typical of a particular stage of development in capitalist societies, had continued after the fall of Fascism, also because the purge of Fascist personnel from the state bureaucracy after the Liberation, he argued, had been a failure. Claudio Pavone, "La continuità dello stato: Istituzioni e uomini," in Italia 1945-48: Le origini della Repubblica, ed. Enzo Piscitelli et al. (Turin: Giappichelli, 1974), 139-289. However, in 1982 Pavone cautioned that the thesis had been pushed too far, resulting in an implicit denial of the new social and political values that had developed through the experience of anti-Fascism and the Resistance, as well as in the new Republican Constitution. Claudio Pavone, "Ancora sulla 'continuità dello Stato,"” in Scritti storici in memoria di Enzo Piscitelli, ed. Renzo Paci (Padua: Antenore, 1982), 537-68.

More recent research on the general historiography of the post-Liberation transition has focused on the legacy of the Fascist "new man" rhetoric. See, in particular, Luca La Rovere, L'eredità del Fascismo: Gli intellettuali, i giovani e la transizione al postfascismo, 1943-1948 (Turin: Bollati Boringhieri, 2008), passim. This approach, however, seems to bring the logic of continuity to new extremes by focusing exclusively on Fascist intellectuals and continuing to ignore the changes brought about by anti-Fascist politics and figures. ${ }^{14}$ Simona Colarizi and Leonardo Morlino have suggested that in studying the postwar transition it is necessary, on the one hand, to consider a broad range of continuity factors beyond those constituted by the apparatuses of the state (e.g., the power of the Catholic 
Church, the role of the middle classes, the emergence of neo-Fascist parties, and the development of mass-party politics), and on the other, to identify the obstacles posed to continuities by new democratic structures, parties, trade unions, and their leaders; the legislation of sanctions against Fascism and the new democratic institutions; political and social pluralism; the referendum of June 1946, which established the Republic; the new Constitution approved at the end of 1947; the spread of anti-Fascist collective values; and anti-Fascist propaganda. See Simona Colarizi and Leonardo Morlino, "Italy after Fascism: An Overview of the Fascist Legacy," in Modern Europe after Fascism, 1943-1980s, ed. Stein Ugelvik Larsen, with Bernt Hagtvet (Boulder: Social Science Monographs, 1998), 457-75. Arguably, the (re)introduction of democracy and pluralism was the key politicalinstitutional factor that generated systemic change in musical production and life. I refer here to democracy and pluralism as articulated in the Constitution approved on 22 December 1947 by the Constituent Assembly elected on 2 June 1946. Article 1 defines Italy as a "democratic republic," where "sovereignty belongs to the people and is exercised by the people in the forms and within the limits of the Constitution," that is, indirectly by elected representatives and directly through vote in general referenda held to repeal laws. Although in Italy the term "pluralism" was not applied to society and politics at the time, it is implied in the Constitution: "All citizens have equal social dignity and are equal before the law, without distinction of sex, race, language, religion, political opinion, personal and social conditions" (Art. 3); and, "Any citizen has the right to freely establish parties to contribute to determining national policies through democratic processes" (Art. 49). See Constitution of the Italian Republic, Parliamentary Information, Archives and Publications Office of the Senate Service for Official Reports and Communication, senato.it/documenti/repository/istituzione/costituzione_inglese.pdf. 
Democracy and pluralism had been eliminated by Fascism. The last elections after the Fascist seizure of power in 1922 took place in 1924, in a climate of violence and coercion, and the intimidation of the opposition. In 1926, Mussolini made all political opposition illegal, and set up a Special Tribunal for the Defense of the State that imprisoned or sent into confinement the opposition activists who had not fled Italy. The new Party Statute of 1926 abolished elections for all party posts. From 1929 on, members of the Chamber of Deputies were chosen by the Fascist Grand Council and the list was approved by voters through plebiscitary election, and in 1939 the nonelected Chamber of Deputies was replaced by the Chamber of Fasces and Corporations. In 1938, the racial laws introduced deliberate discrimination that deprived part of the Italian citizenry of their basic rights and the possibility of participating in society. See, for example, Philip Morgan, Italian Fascism, 1919-1945 (New York: St. Martin’s Press, 1995), 71-78, 83, 84, 92-93, 156, and 162-63.

15 Throughout this article, I refer to La Scala as a "music institution" because, with the engagement of resident conductors such as Luigi Mancinelli, Franco Faccio, Giuseppe Martucci, and Arturo Toscanini, it presented, alongside a winter season of opera and ballet, regular seasons devoted to symphonic and concert music: in the spring, starting in 1879, and since 1925 , in both the spring and fall.

${ }^{16}$ Marla Susan Stone, The Patron State: Culture and Politics in Fascist Italy (Princeton: Princeton University Press, 1998), passim.

${ }^{17}$ For details of the programs, see Nicolodi, “Opera Production,” 197.

${ }^{18}$ For Berezin, while "state control of both cultural products and culture producers yields the classic form of totalitarianism," in which "all cultural products directly represent the state and the state either represses or employs culture producers," under state paternalism "cultural products have a relative autonomy, but the state controls the organizations of culture 
producers." Through this mechanism, "the state militates against artistic dissidence because it promotes self-censorship and encourages culture producers as corporate bodies to represent state ideology." In fact, "the organizational form of the fascist theater, corporativism, carried its ideological message . . because theater was organized according to fascist principles of social order and not because it produced plays about fascist visions of the social order." Mabel Berezin, "The Organization of Political Ideology: Culture, State, and Theater in Fascist Italy," American Sociological Review 56, no. 5 (October 1991): 639-51, here 642 and 646.

Marla Stone has further emphasized the element of consensus sought and received by the Fascist state by acting as a patron of the different artistic movements that existed in Italy at the time. Stone, The Patron State, passim. As a consequence, in her analysis the arts policy of Fascism does not seem to differ radically from that of liberal democratic governments, which suggests continuity on a reverse basis to Pestalozza's argument. In reality, however, the Fascist state obtained consensus only from those artists who had not been forced to flee Italy or been sent to prison or confinement for political reasons when political pluralism was abolished in 1926, or who had not been deliberately discriminated against on national grounds from 1935 or on racial grounds from 1938. Plausibly, such combination of political exclusion of all opposition and deliberate national and racial discrimination is what marks the fundamental distinction between the arts policy of Fascism and those of liberal democratic governments.

${ }^{19}$ Milan was the seat of the Committee of National Liberation for Northern Italy (Comitato di Liberazione Nazionale Alta Italia, CLNAI), which represented the central CLN government in the German-occupied North); the General Command of the Volunteers of Freedom (Corpo Volontari della Libertà, CVL), which led the partisan military formations; and the head offices of all clandestine anti-Fascist political parties in Nazi-occupied Italy. It was in Milan 
that the unified political strategies of the Resistance against Fascism and the German occupier were formulated. In fact, the date of the liberation of Milan-25 April—is commemorated as the national anniversary of the Liberation. See Luigi Borgomaneri, "Milano," in Dizionario della Resistenza, ed. Enzo Collotti, Renato Sandri, and Frediano Sessi, vol. 2, Luoghi, formazioni, protagonisti (Turin: Einaudi, 2001).

20 There is, however, no consensus amongst scholars on the exact chronology of what they refer to as the "transition to post-Fascism." Some consider it to end with the establishment of the Republic on 2 June 1946, others with the first general elections of 1948. Still others dispute the use of the very category of "transition," as they claim it tends to overlook continuities. See Luca Baldissara, "Sulla categoria di 'transizione,”" Italia Contemporanea 254 (March 2009): 1-14. In this article, I use the phrase "post-Liberation transition" because it does not assume continuity or change and does not imply a predefined end date.

${ }^{21}$ Paul Ginsborg, A History of Contemporary Italy: Society and Politics, 1943-1980 (London: Penguin), 113-14.

${ }^{22}$ On the debates, see Irene Piazzoni, Dal "Teatro dei Palchettisti" all'Ente Autonomo: La Scala, 1897-1920 (Florence: La Nuova Italia, 1995), passim.

${ }^{23}$ The expression ente autonomo has been translated into English as a "not-for-profit public corporation under public law, with its own juridical status, and supported by funds from the community," in Nicolodi, "Opera Production," 191.

${ }^{24}$ Enrico Deidda Gagliardo and Mariarita Pierotti, 'Il ‘Teatro alla Scala' di Milano:

Evoluzione dei modelli di governance e del bilancio d'esercizio dal 1921 al 1946,” unpublished paper presented at the Tenth Convegno Nazionale della Società Italiana di Storia della Ragioneria, “Contabilità e Bilanci per l'Amministrazione Economica: Stato ed Istituzioni di Interesse Pubblico in Italia dal XVI al XX Secolo,” Università Bocconi, Milan, 
5-6 November 2009. A version of the paper has been published in English as "The 'Teatro alla Scala' in Milan: The Support of the Financial Statement to Governance Models from 1921 to 1946," paper presented at the Sixth Accounting History International Conference, “Accounting and the State,” Wellington, New Zealand, 18-20 August 2010, victoria.ac.nz/sacl/about/events/past-events2/past-conferences/6ahic/publications/6AHIC65_final_paper.pdf. A key source for this paper is the collection of laws, decrees, and statutes published by the Ente Autonomo Teatro alla Scala, L'ordinamento giuridico del Teatro alla Scala: Raccolta di leggi, decreti, atti, regolamenti e progetti (Milan: Archetipografica, 1963).

${ }^{25}$ On the Fascist reform of the local administration in Milan, see Daniela Bardelli and Pietro Zanetti, "L'amministrazione comunale nel periodo podestarile," in Storia di Milano, vol. 18/1, Il Novecento (Rome: Fondazione Treccani degli Alfieri, 1996), 649-66.

${ }^{26}$ See Gagliardo and Pierotti, "Il 'Teatro alla Scala' di Milano."

${ }^{27}$ Marcello Ruggieri, "Il teatro lirico tra pubblico e privato (1898-2001)," Economia della Cultura, special issue, Il Costo del Melodramma (2004): 39-98. The law of 1936 was the Regio Decreto Legge 3 Febbraio 1936, n. 438, "Disciplina degli Enti Lirici e delle stagioni liriche gestite dai comuni e dagli enti autonomi," in Gazzetta Ufficiale 72 (27 March 1936). ${ }^{28}$ The CLN was an alliance of six anti-Fascist political parties (Communist, Socialist, Christian Democrat, Demo-Labor, Liberal, and Action Party), formed after the armistice of 8 September 1943 to lead and coordinate the Resistance against the German occupation and Mussolini’s Nazi-supported Republic of Salò.

${ }^{29}$ Maddalena Carli, "Mezzasoma, Fernando," in Dizionario Biografico degli Italiani, vol. 74 (Rome: Istituto della Enciclopedia Italiana Fondato da Giovanni Treccani, 2010).

${ }^{30}$ A Ministry of Tourism and Performing Arts was only created in 1959. In 1974 it was replaced by the Ministry of Culture. 
${ }^{31}$ Ente Autonomo Teatro alla Scala, L'ordinamento giuridico del Teatro alla Scala.

${ }^{32}$ Mariuccia Salvati has highlighted that in Italy "the corporatist trend in economic organisation goes back to the twofold — Catholic and socialist — tradition of social mobilisation in the 1900s. The Fascists drew amply on both traditions, and exploited them ideologically, in their attempts to win over the organised masses," but "these two politicocultural milieus . . . existed before Fascism and survived its demise." Mariuccia Salvati, "The Long History of Corporatism in Italy: A Question of Culture or Economics?" Contemporary European History 15, no. 2 (2006): 223-44, here 239-40.

${ }^{33}$ Morgan, Italian Fascism, 88-89.

${ }^{34}$ The re-created unions were linked to the three main anti-Fascist workers' parties (Communist, Socialist, and Christian Democrat) and were brought under the unitary Italian General Confederaton of Labor established in Rome in 1944, just after the liberation of the city. Ginsborg, A History of Contemporary Italy, 61. The right to the free creation of trade unions and their representation was later included in Article 39 of the Constitution, subject to the statutes establishing "their internal organization on a democratic basis." The article also established that their status should be that of "legal persons," which excluded their corporative nature but allowed them the possibility of entering voluntarily into collective labor agreements. The right to strike was included in Article 40. See Constitution of the Italian Republic, Parliamentary Information, Archives and Publications Office of the Senate Service for Official Reports and Communication, senato.it/documenti/repository/istituzione/costituzione_inglese.pdf.

${ }^{35}$ More generally, the role of free and democratic trade unions became so significant in Italian politics after Liberation that Article 1 of the Constitution states: "Italy is a democratic Republic founded on labor." 
${ }^{36}$ See "Storia dell'ente," available at enpals.gov.it/wcmqs/trasparenza-valutazionemerito/ente/. As Mariuccia Salvati has shown more generally, the enti pubblici (social and economic agencies), created by Fascist corporatism as a "second bureaucracy" with a modernizing function and added to the slow traditional bureaucracy of the ministries, survived the end of Fascism because they responded to the ideas of social Catholicism as well as to leftist ideas of central planning. And, "while the enti (and their machinery) remained formally unchanged in their transition from Fascist to postwar Italy, their ideals and culture underwent a radical change, a change that placed the ente pubblico model at the heart of democratic politics.” Mariuccia Salvati, "The Long History of Corporatism in Italy: A Question of Culture or Economics?" Contemporary European History 15, no. 2 (2006): 223-44, here 236.

${ }^{37}$ See, for example, Pavone, "La continuità dello stato"; Roy Palmer Domenico, Italian Fascists on Trial (Chapel Hill: University of North Carolina Press, 1991), passim.

${ }^{38}$ Charles S. Maier, "Fare giustizia, fare storia: Epurazioni politiche e narrative nazionali dopo il 1945 e il 1989," Passato e Presente 34 (1995): 23-32; Charles S. Maier, "I fondamenti politici del dopoguerra," in Storia d'Europa, vol. 1, L'Europa oggi, ed. P. Anderson et al. (Turin: Einaudi, 1993), 313-72.

${ }^{39}$ Hans Woller, I conti con il fascismo: L'epurazione in Italia, 1943-1948 (Bologna: Il Mulino, 1997), 550-51.

${ }^{40}$ No new trials or purges were begun after June 1946, but some trials continued until the 1950s despite a series of amnesties. The last amnesty was issued in December 1953.

${ }^{41}$ Decree of 27 July 1944, n. 159, Sanzioni contro il fascismo, Gazzetta Ufficiale, 29 July 1944, n. 41. The decree summarized all previous legislation and was the main reference text for the sanctions. It was published as Le sanzioni contro i fascistsi: Il testo completo della 
legge per l'epurazione (Bari: Edizioni Nuovo Diritto, 1944). See also Marina Giannetto, "Defascistizzazione: Legislazione e prassi della liquidazione del sistema fascista e dei suoi responsabili," Ventunesimo Secolo 2, no. 4 (2003): 53-90.

${ }^{42}$ See, for example, Toby Thacker, Music after Hitler, 1945-1955 (Aldershot: Ashgate, 2007), passim; David Monod, Settling Scores: German Music, Denazification, and the Americans, 1945-1953 (Chapel Hill: University of North Carolina Press, 2005), passim. ${ }^{43}$ On journalism, see Pierluigi Allotti, “L'epurazione dei giornalisti nel secondo dopoguerra (1944-1946)," Mondo contemporaneo 1 (2010): 5-51; on university professors, see Giovanni Montroni, "Professori fascisti e fascisti professori: La revisione delle nomine per alta fama del ventennio fascista (1945-1947)," Contemporanea 2 (2010): 227-59.

${ }^{44}$ See Montroni, "Professori fascisti e fascisti professori."

${ }^{45}$ On 19 April 1945, the CLN for Northern Italy issued the warning "Surrender or perish!" ( "Arrendersi o perire!"), addressed "to all officials of Fascist and German institutions." It offered them the last opportunity to have their lives spared through unconditional surrender, "today, immediately," to the CLNAI; the abandonment of all official roles; and the handing over of all the relevant documentation. CLNAI, Documenti ufficiali del Comitato di Liberazione nazionale per l'Alta Italia (Milan: CLNAI, 1945), 82-84. In Milan, 622 denounced Fascists were condemned to death or were executed by the partisans, while twenty-two disappeared. Borgomaneri, "Milano."

${ }^{46}$ The list is drawn from the publication L'ordinamento giuridico del Teatro alla Scala.

${ }^{47}$ Giuseppe Colombo, "Nota biografica," in L'ultimo podestà: Il diario inedito di Mario Colombo, ultimo podestà fascista della città di Milano, settembre 1944-26 aprile 1945, ed. Francesco Ogliari (Pavia: Selecta, 2002), xv-xxiii. 
48 “Atti, Seduta della Giunta Municipale del giorno 5 maggio 1945,” Archivi Civici, Comune di Milano, Atti, Fascicolo 3, Anno 1945, n. 2781 Presidenza. The city government of Milan included representatives of all political parties of the CLN alliance for Northern Italy: two Socialists, two Communists, three Christian Democrats, three representatives of the Action Party, two of the Liberal Party, and two of the Republican Party.

${ }^{49}$ Carlo Vallauri, "Greppi, Antonio," in Dizionario biografico, vol. 59 (2003). These objectives emerge quite strongly in Greppi's autobiographical writings, including $L a$ coscienza in pace: Cinquant'anni di socialismo (Milan: Edizioni Avanti! 1963), passim, and Risorgeva Milano (1945-1951) (Milan: Ceschina, 1953), passim.

${ }^{50}$ In his memoirs, Greppi states that the general criteria he followed in decisions of referral to the internal commission were whether the person in question had (1) persecuted anti-Fascists, (2) exercised his or her functions in a biased way, or (3) "done traffic in anything," "collaborated," or "profited from the political situation." Greppi, Risorgeva Milano, 33, my translation.

${ }^{51}$ Greppi calls it a "fever" and "a nightmare," Risorgeva Milano, 33, my translation. 52 “La Scala, in Ruins, Seeking New Life," New York Times, 20 May 1945. We know from subsequent correspondence that this was a CLN commission. Letter from the stage worker to Enrico Tabanelli, Commissione del CLN per l'Ente A. Teatro alla Scala, 15 May 1945, Teatro alla Scala, Archivio Storico (hereafter I-Msc), 1945, 108, I-3-4.

${ }^{53}$ The total number of staff at the time of Liberation is not recorded. In September 1944, the opera house employed around 500 people. Verbale della Seduta del Consiglio di Amministrazione, 14 September 1944, Teatro alla Scala, Archivio di Deposito (hereafter IMsc-d).

54 "La Scala, in Ruins, Seeking New Life." 
${ }^{55}$ Giuseppe Barigazzi, La Scala racconta, rev. ed., ed. Silvia Barigazzi and Franco Pulcini (Milan: Hoepli, 2010), 341-42. Marinuzzi died suddenly in August 1945. Consuelo Giglio, “Marinuzzi, Giovanni, detto Gino senior," in Dizionario biografico, vol. 70 (2007).

56 “Appunti per il Verbale della Seduta del Comitato dell'Ente” (hereafter AVSCE), 2 August 1945, I-Msc-d; “Verbale della Seduta del Comitato dell'Ente” (hereafter VSCE), 9 July 1945, I-Msc-d. Letter from the stage worker to Enrico Tabanelli, Commissione del CLN per l'Ente A. Teatro alla Scala, 15 May 1945, Teatro alla Scala, Archivio Storico (hereafter I-Msc), 1945, 108, I-3-4.

${ }^{57}$ Letter from the stage worker to Enrico Tabanelli, I-Msc, 1945, 108, I-3-4.

${ }^{58}$ During the insurrection of 25 April, the partisans of the CLN had gained control of the city and region, and the CLN for Northern Italy (CLNAI) had issued its own decrees and selected and appointed all provincial and municipal government officers in the region. Though obliged to do so, these officials did not step aside upon the arrival of the American Army, and the AMG decided to retain them. Headquarters Allied Commission, "Report for May 45," and G5, "Fifth Army, Report for April 45," quoted in Harry L. Coles and Albert K. Weinberg, Civil Affairs: Soldiers Become Governors (Washington, D.C.: Center of Military History, United States Army, 1992), 560-61 and 564. From the juridical point of view, after the appointment of the Allied Military Governors of Milan and Lombardy on 2 May, the powers of the CLNappointed officials were those of "local authorities of a foreign government in an occupied country." Aldo Giobbio, "Milano all'indomani della Liberazione," Il Movimento di Liberazione in Italia: Rassegna di Studi e Documenti 69 (1962): 3-36, at 6, my translation. The only exception to this general rule was the application of the sanctions against Fascism, which remained a responsibility of the CLN and then of special commissions. Gaetano Grassi and Massimo Legnani, “Il Governo dei CLN,” Italia Contemporanea 115 (1974): 43-52. 
However, the Commissioner of the Allied Military Government in Milan, Lieutenant Colonel

H. G. Hershenson, established a tactful and friendly relationship with the CLN-appointed mayor, based on the principle of the full respect of their different functions. Greppi,

Risorgeva Milano, 21 and 78-79.

59 "La Scala, in Ruins, Seeking New Life.”

${ }^{60}$ In 1940, sovrintendente and Fascist official Jenner Mataloni recommended Oldani for the

Cavaliere della Corona d'Italia in a letter to Nicola De Pirro, the head of the Theater

Inspectorate of the Ministry of Popular Culture. In the correspondence, Mataloni referred to him as camerata and noted that Oldani had been a member of the Fascist Party since 1932.

Letter from Mataloni to De Pirro, Ministry of Popular Culture, 5 January 1940, I-Msc, 1940, 98, I-6-2.

${ }^{61}$ Meyer Berger, "La Scala Opera to Reopen; Task of Restoring Famous Old House Falls to Young American Lieutenant," New York Times, 9 September 1945. After the war, Clement C. Petrillo taught piano at the Philadelphia Musical Academy (later the Philadelphia College of the Performing Arts and Philadelphia University of the Arts). Da Capo: Philadelphia Musical Academy Yearbook 1963-1964, archive.org/details/yearbook196400phil.

${ }^{62}$ Hans Peter Busch had become a U.S. citizen and had enlisted in the American Army in December 1942. Before arriving in Milan, Sergeant Busch produced several operas in liberated Florence with the Teatro Comunale company in the Verdi theater. "Music in Italy," The Musical Times 86, no. 1229 (July 1945): 223. In 1948, he joined the faculty of Indiana University as director of opera productions. Anthony Tommasini, "Hans Busch, 82, Stage Director of the Indiana University Opera," obituary, New York Times, 29 September 1996; Vera Giannini, "Fritz Busch: A Son Remembers His Father,” The Opera Quarterly 4, no. 2 (1986): 57-74. 
${ }^{63}$ The purge should have been carried out on the basis of the decree of 27 July 1944, n. 159, promulgated by the Italian government in the liberated South, which required that special commissions should be set up to purge the members of all professions, arts, and crafts. 64 "La Scala, in Ruins, Seeking New Life."

${ }^{65}$ On the policy, see Giorgio Bertellini, “Dubbing L'Arte Muta: Poetic Layerings Around Italian Cinema's Transition to Sound," in Reviewing Fascism: Italian Cinema, 1922-1943, ed. Jacqueline Reich and Piero Garofalo (Bloomington: Indiana University Press, 2002), $30-81$.

${ }^{66}$ See, for example, the concerts given by Gigli in support of the charity activities of the Fascist Party in 1930, "Napoli-Concerto del tenore Gigli a beneficio delle Opere assistenziali del Partito," 25 August 1930, photograph A00023654, and in honor of wounded German soldiers at the Italian Embassy in Berlin 1942, "Berlino- Beniamino Gigli si esibisce all'Ambasciata italiana a Berlino in onore dei feriti di guerra tedeschi," 10 August 1942, photographs A00143916 and A00143917, Fondo Luce, Reparto Attualità, Archivio Fotografico, Archivio Storico dell’Istituto Luce, archivioluce.com/archivio/. 67 "Italia settentrionale-Il tenore Beniamino Gigli in visita ad un comando germanico," Giornale Luce C0397, 23 May 1944, Archivio Cinematografico, Archivio Storico dell'Istituto Luce, archivioluce.com/archivio/.

${ }^{68}$ Alessandra Cruciani, “Gigli, Beniamino,” in Dizionario biografico, vol. 54 (2000).

${ }^{69}$ (Harry Beard,) “Music in Italy,” The Musical Times 85, no. 1220 (October 1944): 313-314, at 314 .

${ }^{70}$ Cristina Santarelli, "Schipa, Tito," Dizionario enciclopedico universale della musica e dei musicisti: Le biografie, vol. 6 (Turin: UTET, 1988). 
${ }^{71}$ In August 1942, Schipa appeared in two propaganda cinema newsreels: singing at an official ceremony to honor the armed services and at the inaugural event of the regime's broadcasting services for the military in the presence of the Minister of Popular Culture. "Una grande manifestazione alla Basilica di Massenzio in onore dei combattenti," Giornale Luce C0268, 5 August 1942, and "Roma—inaugurazione della Radio del combattente alla presenza del Ministro Pavolini," Giornale Luce C0271, 13 August 1942, Archivio Cinematografico, Archivio Storico dell'Istituto Luce, archivioluce.com/archivio/.

${ }^{72}$ See, for example, Guido Salvetti, "Ideologie politiche e poetiche musicali nel Novecento italiano," Rivista italiana di musicologia 35, no. 1 (2000): 107-34.

${ }^{73}$ Nicolodi, ”Opera Production,” 197.

${ }^{74}$ Mascagni had thirty productions, Giordano twenty-three, Wolf-Ferrari fourteen, Respighi twelve, Zandonai eleven, Pizzetti nine, Pick-Mangiagalli seven, Montemezzi six, Vittadini five, Casella and Lattuada four each; Ferrari-Trecate, Casavola, Rocca, Ghedini, and Alfano two each; and Lualdi, Refice, Franchetti, Renzo Bianchi, Scuderi, Bianchini, Michetti, Refice, Comussi, Napoli, Gian Francesco Malipiero, Porrino, Marinuzzi, Robbiani, Cattozzo, Sonzogno and Piccioli one each. I have derived the number of productions from the chronology in Giampiero Tintori, Duecento anni di Teatro alla Scala. Cronologia: Opere, Balletti, Concerti, 1778-1977 (Gorle: Grafica Gutenberg, 1979).

${ }^{75}$ Patrizia Ferrara, "Introduzione," in Censura teatrale e fascismo (1931-1944): La storia, l'archivio, l'inventario, ed. Patrizia Ferrara, vol. I (Rome: Pubblicazioni degli Archivi di Stato, Ministero per i Beni e le Attività Culturali, Direzione Generale degli Archivi, 2004), $1-90$.

${ }^{76}$ Mosè was the Italian translation of Moïse et Pharaon, ou Le passage de la Mer Rouge, the 1827 version of Mosè in Egitto. 
77 The works of these composers were not excluded in all of Fascist Italy in the years before the racial laws. For example, Milhaud was invited to conduct his own work at the festival of contemporary music in Venice in 1934.

${ }^{78}$ Castelnuovo Tedesco's one-act Bacco in Toscana, Op. 39 (1925-26), was premiered at La Scala in 1931, and his overture Il mercante di Venezia in 1935. In 1934, Bloch conducted a concert of his own music. Sinigaglia's work had been featured regularly in the concert programs of La Scala since the late nineteenth century. With the promulgation of the racial laws in 1938, Castelnuovo Tedesco fled to the United States and, apart from brief visits, never returned to Italy. Cesare Orselli, "Castelnuovo Tedesco, Mario," in Dizionario biografico, vol. 21 (1978).

${ }^{79}$ Annalisa Capristo, “La Scala, gli ebrei ed Erich Kleiber: Una vicenda antisemita nel dicembre 1938," Quaderni di Storia 67, no. 1 (2008): 205-20.

${ }^{80}$ Giselher Schubert, "Hindemith, Paul," in Grove Music Online, oxfordmusiconline.com/subscriber/article/grove/music/13053.

${ }^{81}$ Berg's Wozzeck (1917-22) was in fact conducted by Serafin as part of a season of "musica contemporanea" sponsored by the Ministry of Popular Culture at the Rome Opera in 1942. For a review, see Franco Abbiati, “'Wozzeck’ di A. Berg al Reale dell'Opera,” Corriere della Sera, 4 November 1942.

${ }^{82}$ Fiamma Nicolodi, “Aspetti di politica culturale nel ventennio fascista," in Italian Music during the Fascist Period, ed. Roberto Illiano (Turnhout: Brepolis, 2004), 97-121.

${ }^{83}$ Nicolodi, “Opera Production,” 203.

${ }^{84}$ (No author, on letterhead of the sovrintendente's office) “Appunto per il Signor Sindaco," 5 May 1945, I-Msc, 1945, 108, I-4-3.

85 “E ciò indipendentemente dal giudizio di epurazione della categoria degli artisti lirici che è 
in corso ed avrà il suo regolare svolgimento," La Scala press release, 16 May 1945, I-Msc, 1945, 108, II-12-1. In reality, a systematic purge of freelance lyric artists never took place. 86 "In onore delle Truppe Alleate presenti in Milano e dei Patrioti Italiani," La Scala press release, 7 May 1945, I-Msc, 1945, 108, II-12-1. "Patriots" arguably referred to partisans who had fought in the Resistance against the occupying Germans.

${ }^{87}$ On jazz in Fascist Italy, see Roberto M. Dainotto, "The Saxophone and the Pastoral: Italian Jazz in the Age of Fascist Modernity," Italica 85, nos. 2-3 (2008): 273-94.

${ }^{88}$ VSCE, 25 June 1945, I-Msc-d.

${ }^{89}$ VSCE, 25 and 28 June 1945, I-Msc-d.

${ }^{90}$ (dictated by O1 [Luigi Oldani],) “Appunto per il Signor Sindaco,” 3 May 1945, I-Msc, 1945, 108, I-4-3; Antonio Trudo, "Porrino, Ennio," in Dizionario biografico, vol. 85 (2016).

${ }^{91}$ Letters from Ricordi to Greppi, 28 June and 24 July 1945, I-Msc, 1945, 108, III-13-1.

${ }^{92}$ Nicolodi, Musica e musicisti, 285; Trudo, "Porrino, Ennio."

${ }^{93}$ Joan Barth Urban, Moscow and the Italian Communist Party: From Togliatti to Berlinguer (London: I. B. Tauris, 1986), 167.

${ }^{94}$ Ginsborg, A History of Contemporary Italy, 85.

${ }^{95}$ It was only after the creation of a cultural commission in January 1948 that the Party developed a specific cultural policy_initially according to Zhdanovist guidelines under Emilio Sereni, and then moving partially away from Soviet influence under Carlo Salinari after 1951 and Mario Alicata after 1955. Albertina Vittoria, "La commissione culturale del PCI dal 1948 al 1956," Studi Storici 31, no. 1, Contributi alla Storia del PCI (1945-1956) (1990): 135-70. On Togliatti's recruitment of intellectuals, see Aldo Agosti, "Le stecche del busto: Togliatti, il PCI e gli intellettuali (1944-1947)," Laboratoire Italien 12, La Vie Intellectuelle entre Fascisme et République: 1940-1948 (2012): 17-32. 
96 Vallauri, “Greppi, Antonio."

97 Thacker, Music after Hitler, 17.

${ }^{98}$ La Scala press release, 19 May 1945, I-Msc, 1945, 108, II-12-1.

${ }^{99}$ Greppi, Risorgeva Milano, 42.

${ }^{100}$ La Scala press release, 15 June 1945, I-Msc, 1945, 108, II-12-1; Greppi, Risorgeva Milano, 53-54.

${ }^{101}$ La Scala press release, 18 June 1945, I-Msc, 1945, 108, II-12-1. The speeches are published in La preghiera di Roosevelt (Milano: Mondadori, 1945).

102 A Harvard Law School graduate who studied international law in Rome, Poletti in 1933 was named counsel to Herbert Lehman in his role as justice of the New York State Supreme Court, and was himself lieutenant governor of New York in 1938, and briefly governor of New York. In 1943 he was named special assistant to the U.S. secretary of war, and in July arrived in Sicily as senior officer of the AMG. He then followed the British and American troops as allied military governor of Naples, Rome, and Lombardy. Richard Goldstein, “Charles Poletti Dies at 99; Aided War-Ravaged Italy,” New York Times, 10 August 2002. ${ }^{103}$ Coles and Weinberg, Civil Affairs, 567.

104 “Seduta della Giunta Municipale del giorno 5 maggio 1945,” Archivi Civici del Comune di Milano, Atti, n. 2781 Presidenza, Anno 1945.

105 VSCE, 25 June 1945, I-Msc-d.

${ }^{106}$ VSCE, 25 and 28 June 1945, I-Msc-d; La Scala press release, 18 June 1945. The commission is referred to as "Comitato" (Committee) in the headings of the minutes, but the headings are entered in pencil and in a different handwriting from the minutes. I therefore use only the approved and signed text of the minutes and the press release.

${ }^{107}$ La Scala press release, 18 June 1945, I-Msc. 
${ }^{108}$ La Scala press release, 18 June 1945, I-Msc.

${ }^{109}$ Greppi, Risorgeva Milano, 125. In July 1945, at the mayor's suggestion and supported by the CLN government in Rome, Ghiringhelli was appointed commissario straordinario of La Scala by the Anglo-American authorities. The appointment was only formalized on 3

September 1945 through letters from Colonel C. Poletti, military governor of Lombardy, and Lieutenant Colonel H. G. Hershenson, commissioner of the Allied Military Government in Milan. These letters (now seemingly lost) are cited in the decree of 28 December 1946 that confirmed Ghiringhelli in the post until 30 June 1947 (Archivio Civico del Comune di Milano, Anno 1949, Fascicolo 14, Ripartizione Educazione).

${ }^{110}$ VSCE, 26 July 1945, I-Msc-d.

111 VSCE, 25 June 1945, I-Msc-d.

112 VSCE, 23 July 1945, I-Msc-d.

113 AVSCE, 2 August 1945, I-Msc-d.

${ }^{114}$ Letter from Mataloni to the Ministry of Popular Culture, Direzione Generale per il Teatro, 28 December 1939, I-Msc, 1939, 95, I-6-4; letter by one of the dismissed chorus members to S. E. Benito Mussolini, 15 November 1939, attached to a letter from the ministry to La Scala requesting explanation, 6 December 1939, I-Msc, 1939, 95, I-6-4.

${ }^{115}$ Franco Abbiati, “La 'Scala' compiti e prospettive," Corriere d'Informazione, 10 November 1945.

${ }^{116}$ See Victoria De Grazia and Luisa Passerini, “Alle origini della cultura di massa: cultura popolare e fascismo in Italia," La Ricerca Folklorica 7 (1983): 19-25; Stefano Cavazza, "La folkloristica italiana e il fascismo: Il Comitato Nazionale per le Arti Popolari," La Ricerca Folklorica 15 (1987): 109-22. 
${ }^{117}$ Vinigi Grottanelli, "Ethnology and/or Cultural Anthropology in Italy: Traditions and Developments," Current Anthropology 18, no. 4 (1977): 593-614.

${ }^{118}$ Harvey Sachs, "La strada diritta," in Arturo Toscanini dal 1915 al 1946: L'arte all'ombra della politica-Omaggio al maestro nel $30^{\circ}$ anniversario della scomparsa (Turin:

EDT/Musica, 1987), 2-19 (catalogue of an exhibition curated by Sachs that was held in Parma in 1987); see also Sachs, Toscanini (London: Weidenfeld and Nicolson, 1978), 289. ${ }^{119}$ Howard Taubman, "Toscanini Is Returning to Milan in February for La Scala Opening," New York Times, 25 August 1945.

120 "La Scala, in Ruins, Seeking New Life."

${ }^{121}$ VSCE, 26 July 1945, I-Msc-d.

${ }^{122}$ Berger, "La Scala Opera to Reopen."

${ }^{123}$ A full account, with photographs and reproductions of articles published by the Italian and German press, can be found in Aldo Montagni, Giro artistico del teatro alla Scala in Germania: Cronache, echi, critiche. 13-23 giugno 1937 (Milan: Rizzoli, 1937), passim.

${ }^{124}$ Raoul Meloncelli, “De Sabata, Victor,” in Dizionario biografico, vol. 39 (1991).

${ }^{125}$ Paolo Patrizi, "Molinari, Bernardino,” in Dizionario biografico, vol. 75 (2011).

${ }^{126}$ See, for example, "Una grande manifestazione alla Basilica di Massenzio in onore dei combattenti," Giornale Luce C0268, 5 August 1942, Giornale Luce C0268, 5 August 1942, Archivio Cinematografico, Archivio Storico dell'Istituto Luce, archivioluce.com/archivio/. ${ }^{127}$ Patrizi, "Molinari."

${ }^{128}$ Nicolodi, Musica e musicisti, 299n.

${ }^{129}$ VSCE, 26 July 1945, I-Msc-d.

${ }^{130}$ AVSCE, 2 August 1945, I-Msc-d.

${ }^{131}$ Rossi remained at La Scala for a few months only, taking up a post as resident conductor 
at the Turin Radio Symphony Orchestra in 1946. "Rossi, Mario," in Enciclopedia Italiana (Rome: Istituto della Enciclopedia italiana fondato da Giovanni Treccani), available at treccani.it/enciclopedia/mario-rossi/.

132 Nicolodi, Musica e musicisti, 299 and 299n. However, as Nicolodi points out, conductors, as freelance professionals, were the only category of musicians allowed to divert from an otherwise strict rule of Fascist Party membership. Serafin's exception was known and tolerated by the Ministry of Popular Culture because the conductor had been appointed to the Teatro Reale by Mussolini, who also gave firm instructions in 1937 that any difficulties should be dealt with in a manner that would ensure the conductor remained at the theater (299n).

133 VSCE, 9 July 1945, I-Msc-d.

134 "Hit at the high levels and indulge at the low levels" to "recuperate the mass of the deluded, the weak and the deceived." Quoted in Galante Garrone, "Il fallimento dell'epurazione," preface to Roy Palmer Domenico, Processo ai fascisti, 1943-1948: Storia di un'epurazione che non c'è stata (Milan: Rizzoli, 1996), xii-xiii, my translation.

${ }^{135}$ Commissione per l'epurazione del personale dipendente dell'E.A. Teatro della Scala, 6 June 1946, I-Msc, 1946, 109, II-11-1. The commission was chaired by a judge and included a representative of the High Commissariat for the Sanctions against Fascism.

${ }^{136}$ AVSCE, 2 August 1945, I-Msc-d.

137 (Beard,) "Music in Italy."

${ }^{138}$ AVSCE, 2 August 1945, I-Msc-d.

${ }^{139}$ AVSCE, 2 August 1945, I-Msc-d.

${ }^{140}$ Fiamma Nicolodi, "Mascagni e il potere," in Claudio Casini et al., Mascagni (Milan:

Electa, 1984), 195-225. In a propaganda film of 1935, Mascagni, in Fascist uniform, conducts 
a brass band and then, in black shirt, performs the Fascist salute and conducts a chorus of 7,000 members of the OND. "Manifestazione musicale dell'O.N.D. Concerto bandistico Mascagni. Concerto di 7000 dopolavoristi diretto da Pietro Mascagni alla presenza del Duce," 1935, Archivio Cinematografico, Archivio Storico dell'Istituto Luce, archivioluce.com/archivio/.

141 Virgilio Bernardoni, "Mascagni, Pietro,” in Dizionario biografico, vol. 71 (2008).

142 Nicolodi, "Mascagni e il potere."

143 Virgilio Bernardoni, “Mascagni, Pietro," in Dizionario biografico 71 (2008). The opera as conducted by the composer was recorded on 14-20 April 1940 at the Milan Conservatory with the orchestra and chorus of La Scala. The cast included Beniamino Gigli, Lina Bruna Rasa, Giulietta Simionato, Gino Bechi, and Maria Marcucci. The recording is available commercially as Naxos CD 8.110714-15.

144 Ibid.

${ }^{145}$ La Scala press release, 12 December 1945, I-Msc, 1945, 108, II-12-1.

${ }^{146}$ Nicolodi, Musica e musicisti, 63; Raoul Meloncelli, "Giordano, Umberto," in Dizionario biografico, vol. 55 (2001). The Inno imperiale, which set to music the Duce's sentence "Salutate l'Impero che riappare sui colli fatali di Roma," is documented in Giordano's correspondence with Mussolini, but is lost. Nicolodi, Musica e musicisti, 63, 63n, and 64n. ${ }^{147}$ Raoul Meloncelli, “Cilea, Francesco,” in Dizionario biografico, vol. 25 (1981).

${ }^{148}$ Nicolodi, Musica e musicisti, 69.

${ }^{149}$ La Scala press release, 23 November 1945, I-Msc, 1945, 108, II-12-1. Toscanini had performed the work's American premiere in 1942 with the NBC Symphony Orchestra. ${ }^{150}$ VSCE, 25 June 1945, I-Msc-d. 
151 The Socialists received 225,287 votes, the Christian Democracts 167,314, and the Communists 155,139 . Greppi led a city government comprising seven Socialists, six Communists, and six Christian Democrats, and could count on an elected city council with Socialist majority. A Communist was appointed deputy mayor. Ciro Fontana, All'ombra di Palazzo Marino: 1941-1981 (Milan: Mursia, 1981).

152 Vallauri, “Greppi, Antonio.” Greppi was elected but resigned in September to focus on his role as mayor, an office to which he was reelected until 1951, and as president of the La Scala board.

153 Ginsborg, A History of Contemporary Italy, 89-93 and 105.

${ }^{154}$ Greppi, Risorgeva Milano, 126. Greppi articulated his concerns in a personal note to Ghiringhelli: "Also the Arena, also the remotest of the sport grounds, also the remotest of the neighborhood circles, has been rebaptized with a minimum of spiritual concentration. ... This will help people not to forget. We already have to let pass too many things" (Anche l'Arena, anche l'ultimo campo sportivo, anche l'ultimo circolo rionale è stato ribattezzato con un minimo di concentrazione spirituale. Così deve essere dunque, e a maggior ragione, della Scala. ... Servirà anche questo a non dimenticare. Si passa già sopra a troppe cose). Quoted in V. Poggiali, Antonio Ghiringhelli: Una vita per la Scala (Urbino: Quattro Venti, 2004) 79, my translation.

${ }^{155}$ Barigazzi, La Scala racconta, 346. In his memoirs, however, Greppi implies that he heard the performance, possibly in the Piazza Scala, where it was broadcast, as a private citizen in the crowd gathered for the occasion, or perhaps listening from the balcony of the municipality's offices (Palazzo Marino, opposite La Scala in the Piazza), or from the radio: "I I was thinking of the martyrs and the heroes. And for me it was as if all those pieces of music formed a single symphony, epic and religious. For them! Only for them!" (Io pensavo 
ai martiri e agli eroi. E per me era come se tutti quei brani componessero una sola sinfonia, epica e religiosa. Per loro! Soltanto per loro). Greppi, Risorgeva Milano, 126, my translation. ${ }^{156}$ Jane F. Fulcher, "The Concert as Political Propaganda in France and the Control of 'Performative Context,"” The Musical Quarterly 82, no. 1 (1998): 58, 42, and 47.

157 “Maestro Returns,” New York Times, 21 April 1946; “Toscanini to Leave for Italy April 17,” New York Times, 23 March 1946.

${ }^{158}$ Effie G. H. Pedaliu, Britain, Italy and the Origins of the Cold War (Basingstoke: Palgrave Macmillan, 2003), 39-41; Alessandro Brogi, Confronting America: The Cold War between the United States and the Communists in France and Italy (Chapel Hill: The University of North Carolina Press, 2011), 72-74.

159 “Rivive la Scala,” Avanti! 10 May 1946; Sachs, Toscanini, 290.

160 “An Italian Manifesto: Six Eminent Italian Expatriates Condemn Allied Policy in Italy and Demand a Rebirth of Freedom," Life, 12 June 1944; partially reprinted as item 172 in Arturo Toscanini dal 1915 al 1946, 109.

161 This is demonstrated by the wealth of documents reproduced in Arturo Toscanini dal 1915 al 1946.

162 Sachs, Toscanini, 287.

${ }^{163}$ Quoted in "Toscanini Rejects Plea of Milanese; Refuses to Return as Subject of 'Degenerate King,' but Praises Patriots' Spirit,” New York Times, 5 May 1945.

${ }^{164}$ Sachs, Toscanini, 287-78.

165 This is also demonstrated by the documents reproduced in Arturo Toscanini dal 1915 al 1946.

166 A live recording of the concert was released in 1999 as Toscanini: Reopening of La Scala Concert, Naxos CD 8110821-22. 
${ }^{167}$ Ruth Steiner et al., "Te Deum,” in Grove Music Online, oxfordmusiconline.com/subscriber/article/grove/music/27618.

${ }^{168} \mathrm{La}$ Scala examples were the concert conducted by Mascagni in 1898 to celebrate the fiftieth anniversary of the 1848 insurrection of the Milanese against the Austrian occupation (Cinque Giornate di Milano) and the "Serata patriottica dedicata agli alleati" conducted by Tullio Serafin in November 1917, with a speech by, among others, the young Mussolini. ${ }^{169}$ Philip Gossett, in his article "Becoming a Citizen: The Chorus in 'Risorgimento' Opera," Cambridge Opera Journal 2, no. 1 (March 1990): 41-64, has highlighted the link between opera and the Risorgimento, while Roger Parker has cautioned against deducing a political character from the political context or later (postunification) ideological constructs. See Roger Parker, "Arpa d'or dei fatidici vati": The Verdian Patriotic Chorus in the 1840s (Parma: Istituto Nazionale di Studi Verdiani, 1997). What matters for my discussion is that a public association between a particular repertoire and the Risorgimento had been made at some point in history.

${ }^{170}$ Toscanini conducted a highly publicized patriotic all-Verdi concert at the arena in Milan for an audience of 40,000 on 26 July 1915 to benefit the war effort, an experience he recalled with enthusiasm in 1937 in a letter to Ada Mainardi. Harvey Sachs, ed., Nel mio cuore troppo d'assoluto: Lettere di Arturo Toscanini (Milan: Garzanti, 2003), 409. The concert included, for example, the overtures to La forza del destino and I vespri siciliani, "Va' pensiero" from Nabucco, "Inno e giuramento" from La battaglia di Legnano, and Inno delle nazioni, and concluded with Garibaldi’s and Mameli’s Risorgimento hymns.

${ }^{171}$ As an interventionist and a volunteer at the front, where he had conducted a military band, Toscanini was invited in 1920 by Gabriele D’Annunzio to perform with the La Scala orchestra in Fiume to celebrate the poet's ultranationalist venture and his volunteer 
"legionaries" occupying the city. The ideological frame provided by D'Annunzio's speeches during the visit was one of exalted, spiritualistic belief in the fundamental social and pedagogic role of music in the life of the warring city-state, and of the conductor as a supreme symbol of charismatic leadership in battle. See Renato Ricco, “'Esaltatrice dell'atto di vita, dell'opera di vita': Il ruolo della musica nella Carta del Carnaro di Gabriele d'Annunzio," Forum Italicum 49, no. 2 (2015): 433-46.

${ }^{172}$ Claudia Polo, Immaginari verdiani: Opera, media e industria culturale nell'Italia del XX secolo (Rome: Accademia Nazionale di Santa Cecilia-Ricordi, 2004), 199.

${ }^{173}$ Urban, Moscow and the Italian Communist Party, 184-89 and 209. 